\title{
The nature of rainfall in the main drainage sub-basins of Uganda.
}

\author{
Francis W.N, Nsubuga ${ }^{1}$, O.J. Botai ${ }^{2}$, Jane M. Olwoch ${ }^{3}$, C.J.deW Rautenbach ${ }^{4}$, Yvette Bevis ${ }^{5}$, \\ Adebayo, O. Adetunji ${ }^{6}$. \\ 1,2,4,5 Department of Geography, Geoinformatics and Meteorology University of Pretoria. \\ ${ }^{3}$ South African National Space Agency \\ ${ }^{6}$ Department of Town and Regional Planning
}

\begin{abstract}
A study of rainfall trends and temporal variations within seven sub- basins of Uganda spanning from 1940 to 2009 has been made. Rainfall climatologies are constructed from observational data, using 36 station records which reflect hydro climatic conditions. Long-term changes in rainfall characteristics were determined by non-parametric tests (Mann-Kendall and Sen's $T$ tests), coefficient of variation, precipitation concentration Index and drought severity index. Magnitude of change was estimated by applying Sen's estimator of slope. Decadal variability of rainfall with marked seasonal cycles is evident. Temporal variability of drought patterns is detected. Variations in annual rainfall are low with no significant trends observed in the main drainage sub-basins. Significant trends occur in October, November, December and January. A noticeable decrease in the annual total rainfall was observed mostly in north-western and south-western sub-basins. Rainfall trend in the second normal of June-July-August (JJA) was decreasing in all the main drainage sub-basins.
\end{abstract}

Key words Trend analysis, Uganda, drainage sub-basins, Mann-Kendall, Sen's T test, precipitation concentration index, drought severity index

\section{$1 \quad$ Introduction}

Rainfall, which is the main input to the global hydrological cycle, is one of the most important natural resources that has recently shown significant variations both regionally and globally. Such variation can have profound effects on the availability of water resources, especially those, which derive significant, recharge from rainfall (Ngongondo 2006). Thus it is important to monitor closely the rainfall variation on monthly seasonal and annual time scales in order to manage water resources well. For example $80 \%$ of the total catchments of Lake Victoria in east Africa rely on direct rainfall while the remaining $20 \%$ comes from the river and underground discharges (Awange et al. 2008). Rainfall is also very important for the economic development,

\footnotetext{
1e-mail: nwasswa@gmail.com

2 joel.botai@up.ac.za

3 jolwoch@sansa.org.za

${ }^{4}$ hannes.rautenbach@up.ac.za

${ }^{5}$ yvette.bevis@gmail.com

6 adebayo.dev planning@yahoo.com
} 
disaster management and hydrological planning of a country. This natural resource and the associated variables like temperature, runoff and ground water are commonly used to characterize the climatic state of a region (Kothyari and Singh 1996). Careful assessment of the magnitude and extent of these variables are used as indicators of climatic change. Uganda as a region experiences varied rainfall whose effects are especially noticeable in the eastern part, where drought has been reported to be frequent in the last decades and has drastically altered the landscape. Some areas in Uganda receive rains that have resulted in floods every year, which destroy property worth million of Uganda shillings. This kind of weather has evoked considerable speculations that the country's rainfall characteristics are changing. Detecting rainfall changes over recent decades is needed, together with an appreciation of those characteristics of rainfall supply that are most essential for its effective utilization as a resource and those which are most sensitive to change (Hulme 1992). Uganda's economy is still dependant on agriculture, so extreme events like floods, famine, and drought or crop failure become very critical to the country. Climate change and variability exacerbates the socioeconomic woes of Uganda especially in the light of pressures of trying to achieve food security and alleviate poverty. Furthermore, Uganda has just come out of civil war but still experiences political volatility, worsening terms of international trade, rapid population growth and HIV. Variability and trends in rainfall is one of the important aspects of climate change studies (Patra et al. 2011) and worldwide there is a lot of literature on both spatial and temporal variation of rainfall. For example, Ruiz Sinoga et al (2011) points out studies of temporal variability and trends in precipitation at both global and regional scales in the last 25 years. Very large spatial and seasonal variability, with implications for water management and risk assessment in the north eastern Iberian Peninsula were revealed by (Lopez-Moreno et al. 2009). Zhao et al (2011) used the entropy method to detect the spatial variability of precipitation over temporal scales in Xinjiang which, showed that precipitation was increasing especially in mountainous regions. Rai et al (2010) observed falling trends in temporal scales including aridity index over the Yamuna river basin in India. Moderate to high variations in inter and intra annual rainfall have been identified by Shahid and Khairulmaini (2009) in Bangladesh. While Ngongondo (2006) found out that annual rainfall and groundwater in Mulunguzi river catchment area had declined by up to $15 \%$ and $50 \%$ respectively, since 1954 .

Recent studies of rainfall fluctuations in Uganda e.g (Nsubuga et al. 2011) have demonstrated that total rainfall during the March to May season and the number of wet days at Namulonge were decreasing. Kizza et al (2009) found positive trends at most stations located in the northern part of the Lake Victoria basin especially in the short rains than in the long rains. Nicholson (1996) also revealed that interannual variability of rainfall is remarkably coherent throughout most of eastern Africa especially during the October to December season and a dominant time scale of variability of 5 to 6 years. Phillips and Mcintyre (2000) investigated Pacific El NiñoSouthern Oscillation (ENSO) and interannual rainfall variability in relation to agricultural management in Uganda. They discovered that, pacific Ocean NINO3 region sea surface temperatures from July to September are significantly correlated with both August- September and November-December rainfall but with opposite signs. In another related study by Nyenje and Batelaan (2009) about the effects of climate change on ground water system of the upper Ssezibwa catchment in Uganda, found evidence of increasing temperature trends and decreasing trends in river discharge especially from 1990. No significant trends were observed in precipitation, though it is predicted to increase by over $30 \%$ and $100 \%$ especially in short and long rain seasons in the 2020 s and 2080s respectively. The point of departure in this study in 
relation to previous work is: 1) the wider scope of investigation using stations spread across the country in seven sub-basins; 2) two non-parametric technique are used in conjunction with other indices to establish trends and characterise rainfall in the different drainage sub-basins. The debate about the different results that are sometimes reported (e.g GOU 2007) triggered the study presented here. The main contribution of the present work is to build on previous studies by utilizing data spanning seven decades and results would support policy with regard to water resource management under changing climate across Ugandan sub-basins. In this regard, the study aimed at analysing the evolution of precipitation values at different time scales (monthly, seasonal, intra-annual and annual) as well as the spatial patterns of rainfall trends in the main drainage sub-basins of Uganda.

\section{Data and analysis methods}

\subsection{Study area}

Uganda is situated in the eastern part of Africa. It covers an area of nearly $241548 \mathrm{~km}^{2}$ having $0.8 \%$ of total geographical area of the continent. The exact geographical location lies between $1^{0}$ 30 ' South to $4^{0}$ North latitude and $29^{0} 30^{\prime}$ East to $34^{0}$ East longitude and it is landlocked. The country shares a total length of $2698 \mathrm{~km}^{2}$ of international borders with its neighbours (Uganda National Water Development Report-UNWDR, 2005). Its climate is much influenced by latitude, orographic aspects and the proximity to water bodies. The country has a modified climate characterised by high temperature, high humidity, and high rainfall. The annual rainfall varies from $500 \mathrm{~mm}$ to $2800 \mathrm{~mm}$, with an average of $1180 \mathrm{~mm}$ (NEMA, 2008). The spatial pattern of rainfall in Uganda is complex and arises from the interaction of a number of different forcing factors including; large-scale patterns which are dominated by convective rainfall from the seasonal migration of the Inter-tropical Convergence Zone (ITCZ) as it follows the path of the overhead sun, modulated by the complex topography and the presence of lakes. This leads to two main rainfall seasons: the long rains in March, April and May (MAM) and the short rains in September, October and November (SON).

Generally, the seasonal pattern follows this bimodal system near the Equator and tends to a unimodal system away from the Equator (Conway 2005, Asadullah et al. 2008). Inter-annual variability of rainfall correlates with sea-surface temperatures (SST) in the Pacific through atmospheric tele- connections the El Niño/Southern Oscillation (ENSO) phenomenon. Highest totals are generally observed in the mountainous regions in the southwest and east and in the vicinity of Lake Victoria. The lowest rainfall totals are found in the north east of the country on the border with Kenya and Sudan where drought is a common occurrence (NARO 2001). The country is pleasantly cool with a long-term mean temperature of $21^{\circ} \mathrm{C}$. Annual temperature range from a minimum of $15^{\circ} \mathrm{C}$ in July to a maximum of $30^{\circ} \mathrm{C}$ in February. The economic activities that the country depends on include among others, agriculture, tourism, Industry and services. These are key sectors of the economy, which are controlled by climate. In particular, the percentage share of some of these sectors to GDP in 2011 according to UBOS was $24.1 \%$ for agriculture, $26.9 \%$ for industry and $49.0 \%$ for services (MOFPED 2011). Agriculture continues to determine Uganda's success in terms of economic growth and poverty reduction because it absorbs the largest share (73\%) of the labour force (NEMA 2008). Uganda has been divided into eight drainage sub-basins, which drain into the Nile as shown in Figure.1 below. The eight subbasins, here ranked by area from the largest to the smallest are; Lake Victoria, Lake Kyoga, 
Victoria Nile, River Aswa, Albert Nile, Lakes Edward, Lake Albert, and Kidepo valley (UNWDR 2005).

\subsection{Data pre-processing}

Monthly rainfall data $(\mathrm{mm})$ over the study area was obtained from Uganda Department of Meteorology (UDM) and as well as from the Uganda Bureau of Statistics (UBOS). The raw data sets from UDM are archived as monthly values using climate-computing format. A basic data quality check such as abnormal values in the data sets was assumed in the current study as this was confirmed by UDM staff. Stations considered in the present study were selected based on the length of time and record of areal coverage. In total, 36 Ugandan rainfall stations depicted in Fig. 1 were considered. Some station records commence in the 1925 s or 1930 s and nearly all cover at least the period 1940 to 1999. Overall, stations over selected sub-basins namely, Albert Nile, Lake Albert, River Aswa, Lake Edward, Lake Kyoga, Lake Victoria and Victoria Nile (see basin characteristics in Fig.1) were used for the study. Kidepo sub-basin was dropped because much of its water drains into the neighbouring countries up north.

One of the limitations of raw data sets was the presence of missing values. Thus gaps were filled using long-term monthly mean values (i.e., month climatology) of a particular month for that station because in some instances, stations had consecutive missing values (up to a whole year). The authors felt that using interpolation to fill in the missing data gaps could not be robust. Furthermore, seasonal and annual totals records for each station were derived from the monthly data records The series were then normalized to minimize any resultant inhomogeneities in the regional series that may be brought about by varied record length and missing data (Nicholson, 1986).

For this study, the original monthly precipitation series were normalized into monthly series $\left(\mathrm{M}_{\mathrm{sy}}\right)$ by subtracting the long term mean $\overline{R_{s}}$ from the original monthly values $R_{s y}$ and then divide by standard deviation $\sigma_{s}$ at each station. This process minimizes the problem of highly diverse means and variability and the randomness of the convective process reflected in the individual station totals (Nicholson 1986). The normalized monthly rainfall anomaly for a given station is;

$$
M_{s y}=\left(R_{s y}-\overline{R_{s}}\right) / \sigma_{s}
$$

Rainfall anomaly series were constructed for the seven sub-basins in Uganda (Figure.1) using individual station time series. Annual and monthly totals for individual stations are transformed into regional rainfall departure series in a procedure described more fully by Nicholson (1986). In the present study, the area-averaged (regional mean climatology or sub-basin climatology) normalized monthly rainfall anomaly $\left(M_{r y}\right)$ for a given region/sub-basin was defined as;

$$
M_{r y}=\left(1 / N_{j}\right) \sum_{s=1}^{N_{s}} M_{s y}
$$

where $N_{j}$ is the number of regional stations operating in the year $j$. The use of regional average, in general, provides a time series that is a better representation of large-scale climatic processes (Partal and Kahya 2006), thus making it easier to deal with one index series in a region. Before 
one can use the $M_{r y}$ series with confidence for the discussion and analysis of regional month-tomonth and year-to-year fluctuations, it has to be demonstrated that it is indeed representative for the region as a whole (Kraus 1977, Nicholson 1986, Türkeş 1996). The validity of regionalization for all series was tested in the present study using correlation coefficients and an analysis of variance (Nicholson 1986). Analysis of variance compares the temporal and spatial variance i.e., investigate if $\mathrm{M}_{\mathrm{sy}}<M_{r y}$. Kraus (1977) demonstrates that the variance in time can be estimated as;

$$
v(\text { time })=\frac{\sum N_{j} M_{r y}{ }^{2}}{J-1}
$$

where $N$ is the number of regional stations operative in the year $j$ and $J$ is the number of years of record for the series $M_{r y}$. The mean spatial variance between rainfall anomalies within the region is estimated as;

$$
v(\text { area })=\frac{n-\sum N_{j} M_{r y}^{2}}{n-J}
$$

where $n$, the total number of stations years, is calculated as;

$$
n=\sum_{j} N_{j}=\sum_{i} J_{i}
$$

The statistical importance of variance estimates (Variance in time/variance in area) was then determined by the $F$ test (Türkeş 1996). Validity of regionalization of all series was also tested using correlation coefficients. Like Nicholson (1986), stations correlating at less than 0.4 with the regional series were dropped (or reassigned) and the regional series recalculated, omitting data for that station. For the 36 stations in the drainage sub-basins of Uganda, correlations are generally between 0.50 and 0.80 . Further analyses using regional area -average normalized series was therefore sufficient.

\subsection{Methodology}

Rainfall patterns across the different sub-basins were characterized using statistics such as; mean, standard deviation (SD), coefficient of variation (CV) and percentage contribution to annual were computed for monthly and season-wise viz., December- January- February (DJF), March- April- May (MAM), June- July - August (JJA) and September- October- November (SON). Furthermore, the Precipitation Concentration Index (PCI) proposed by Oliver (1980 in Shahid and Khairulmaini 2009) was used to analyse the annual rainfall distribution. In the present work, PCI is expressed as a percentage in accordance to the following formula (De Luis et al. 2000, Ceballos et al. 2004): 


$$
P C I=100 . \frac{\sum_{i=1}^{12} p_{i}^{2}}{\left(\sum_{i=1}^{12} p_{i}\right)^{2}}
$$

In equation $6, P_{\mathrm{i}}$ is the rainfall amount of the $i^{\text {th }}$ month, calculated for each of the stations and for each of the year (period) being considered. The degree of seasonal concentration of precipitation and the information to compare different climates in terms of seasonality of precipitation regimes are some of the aspects the PCI can be of advantage. The more concentrated is precipitation, the more difficult is water management, irrigation control, soil erosion prevention and rain fed agriculture (Shahid and Khairulmaini 2009). In order to show the spatial distribution of intra- and inter-annual variability or rainfall in Uganda's main drainage sub-basins, $P C I$ and the coefficient of variation of annual rainfall for each of the station is calculated and then interpolated using Kriging method (Shahid and Khairulmaini 2009 and references there in). For mapping of spatial characteristics of rainfall, mean annual rainfall, precipitation concentration index and trends are calculated for each sub-basin. GIS is used for the development of historical rainfall database and calculation of rainfall characteristics at each subbasin. Raster maps of rainfall characteristics are prepared from regional data using kriging interpolation method.

Using rainfall data computed from equations put forward by Awange et al.(2008), seasonal means were obtained by averaging the monthly totals for three months of a particular season, i.e.,

$$
\overline{S_{m}}=\frac{1}{3} \sum_{m=1}^{3} M_{t}
$$

While for annual totals, the summation of twelve monthly totals was taken for a given year.

$$
A_{t}=\sum_{m=1}^{12} M_{t}
$$

These were further categorized into the 30-years 'normal' in accordance with World Meteorological Organization (WMO) requirement (Awange et al. 2008). Using rainfall data computed from equation (7) and (8), the normal precipitation $N$ - typically considered a 30 -year mean is obtained. The normal precipitation is then used to compute the percentage of normal $P_{n}$ (quartile) using.,

$$
P_{n}=\left[\frac{A_{p}}{N}\right] \times 100
$$

In equation $9, A_{p}$ is the actual precipitation. Using the percentage of normal from equation (9), a Drought Severity Index (DSI) was determined by considering all observations which are less than $25 \%$ (first quartile) of the ranked historical records to be dry, while those which are more than 75\%(third quartile) are considered wet. Awange et al (2008) illustrates severity classification as shown in the scale below: 


\begin{tabular}{|l|l|l|l|l|l|}
\hline Wet & $>75 \%$ & Near normal & $25-75 \%$ & Drought & $<25 \%$ \\
\hline
\end{tabular}

Drought seasons and years were identified by observing the years and seasons in which the anomalies were below the drought threshold line (i.e., DSI of $25 \%$ ).

In order to investigate for the presence of trends in the data sets, Mann-Kendall test was used. This test, which is also known as Kendall's $t$ statistic, is a non-parametric method that has been widely used to test for randomness against trend in hydrology and climatology. It is a rank based procedure, which is robust to influence of extremes and good for use with skewed variables (Nsubuga et al. 2011, Partal and Kahya 2006, CRCCH 2005, Yue et al. 2002, De Luis et al. 2000). The null hypothesis $H_{o}$ of no trend (i.e., the observations are randomly ordered in time) is tested against the alternative hypothesis, $H_{l}$, associated with increasing or decreasing monotonic trends (de Lima et al.2010). In this work the null hypothesis is tested at 5\% significance level, taken in its two-sided form. This method accounts for missing values, serial correlation and numbers below detection limit that commonly confound trend detection procedures in time series analysis (Hirsch and Slack 1984). The $M K$ statistics has the advantage of making no assumptions about the statistical distribution of variables (Kampata et al. 2008). Furthermore, the Sen's T test was also used for trend analysis. Sen's T test, is an aligned rank method having procedures that first remove the block (season) effect from each datum, then sum the data over blocks, and finally produce a statistic from these sums. The aligned rank test is more powerful, its distribution free and not affected by seasonal fluctuations (Partal and Kahya 2006 and references there in). The procedure used in the present analysis was outlined by Partal and Kahya (2006), takes the following steps;

a) $\quad x_{\cdot_{j}}$ and $x_{i}$ are computed for averages of $j$ th month and $i$ th year as

$$
x_{j}=\frac{\sum_{i}^{n} x_{i j}}{n} \quad \text { and } \quad x_{i}=\frac{\sum_{i}^{m} x_{i j}}{m}
$$

b) Subtract the monthly average from each of the corresponding months in the $n$ years of data to remove monthly or seasonal effects.

c) All differences obtained from step 2 are replaced by its ranks, resulting in a similar table with the notation of $R$ instead of $X$. It is important to note that the integer 1 would be assigned to the smallest difference, whereas the integer $\mathrm{nm}$ would correspond to the rank of the highest difference. Hence, $R_{j}$ refers to the rank of $\left(x_{i j}-x_{._{j}}\right)$, where $i=1, \ldots, n$ and $\mathrm{j}=1, \ldots, m$. For each of the $t$ tied values, the average of the next $t$ ranks is assigned.

d) Calculate the test statistic:

$T=\left[\frac{12 m^{2}}{n(n+1) \sum_{i . j}\left(R_{i j}-R_{j}\right)^{2}}\right]^{1 / 2}\left[\sum_{i=1}^{n} i-\frac{n+1}{2}\right)\left(R_{i}-\frac{n m+1}{2}\right]$ 
The test statistic $T$ follows an $N(0,1)$ distribution under the null hypothesis of no trend. If $|T|>z \alpha$, then a significant trend exists in the time series under consideration. Positive values of $T$ indicate an 'upward trend' and negative values the opposite.

The non-parametric method proposed jointly by Theil 1950 and Sen 1968 was used to estimate the magnitude of trends. This approach uses the Sen's slope estimation method by assuming the trend to be linear, such that $f(t)=Q(t)+B$, where $Q$ is the gradient of the linear trend and $B$ is the constant. If a linear trend is present in a time series, then the true slope (change per unit time) can be estimated by using a simple non-parametric procedure developed by Sen 1968 b in (Partal and Kahya 2006). The slope estimates of $\mathrm{N}$ pairs of data are first computed by

$$
Q_{i}=\frac{x_{j}-x_{k}}{j-k} \quad \text { for } i=1, \ldots ., N
$$

where $x_{j}$ and $x_{k}$ are data values at times $\mathrm{j}$ and $\mathrm{k}(j>k)$ respectively. The median of the $N$ values of $Q_{i}$ is Sen's estimator of slope. If $N$ is odd, then Sen's estimator is computed by $Q_{m e d}=Q_{(N+1) / 2}$ and if $\mathrm{N}$ is even, then Sen's estimator is computed by $Q_{\text {med }}=\left\lfloor Q_{N / 2}+Q_{(N+2) / 2}\right\rfloor / 2$. Finally, $Q_{\text {med }}$ is tested by a two sided test at the $100(1-\alpha) \%$ confidence interval and the true slope may be obtained by the non-parametric test. This technique has been used widely to verify the magnitudes of trends, e.g Zhang et al (2000), Yue and Hashino (2003) and Partal and Kahya (2006). Sen's slope is insensitive to outliers or missing data and more rigorous than the usual regression slopes and thus provides us a realistic measure of trends in the data series. The data analyses steps considered in the current study are depicted in figure 2 .

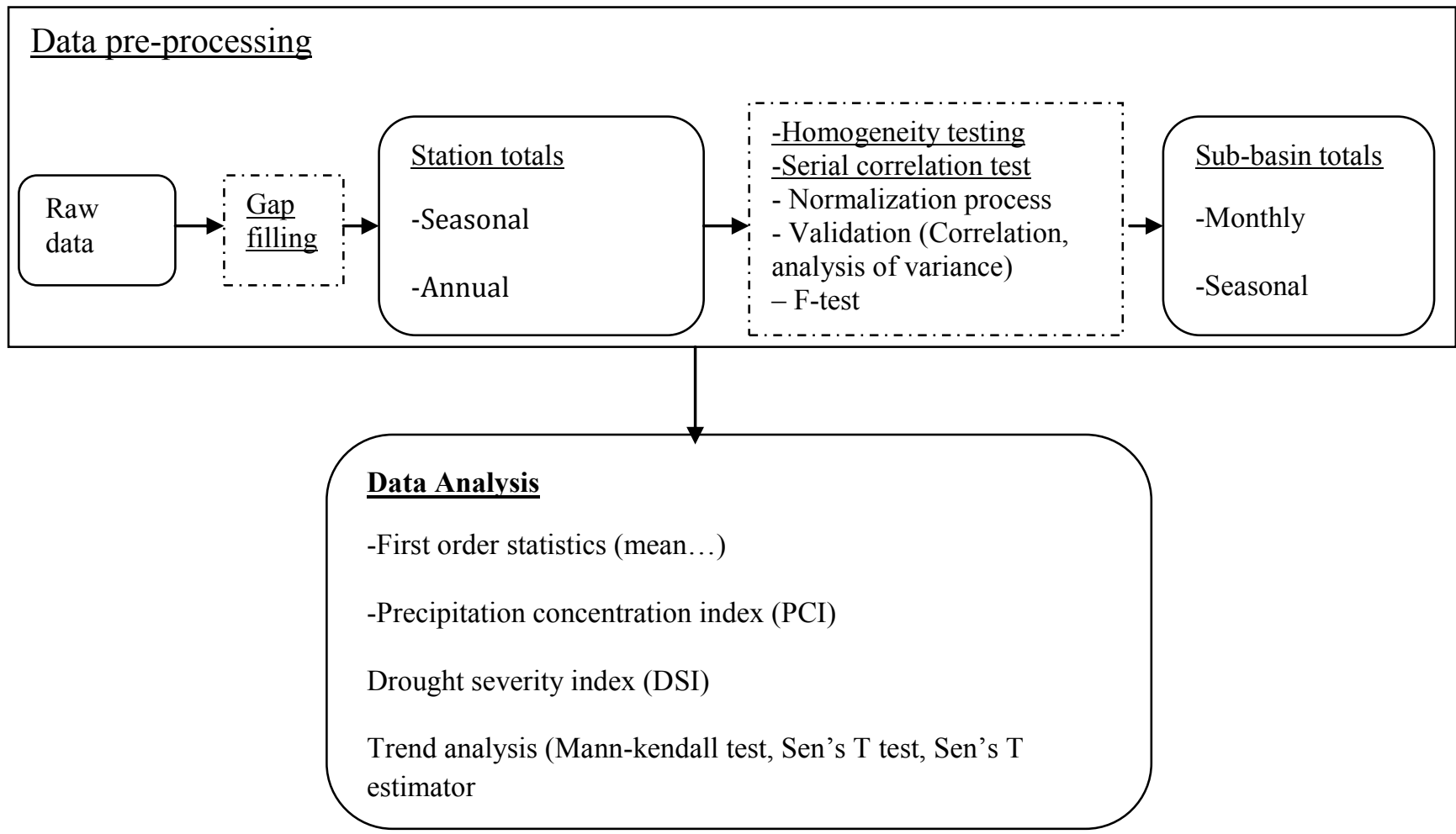


Figure 2 Steps in data pre-processing and analysis for the study.

\section{Results and discussion}

For this present analysis a subset of 36 stations is used to derive areally averaged departure series for 7 sub-basins. The locations of these stations in each sub-basin are shown in Fig. 1. The highest and lowest values of annual total rainfall, with years of occurrence, for each station in the respective drainage sub-basin are shown in Table 1.

Serial correlation effect. Bold figures indicate series, which are serially correlated. Annual series of 18 stations show that data does not come from the same random process. The results reveal a significant serial correlation value in $51 \%$ of the 36 stations (Table 1). The locations of the stations with a significant serial correlation were, for the most part, in central Uganda, especially in the Lake Victoria sub-basin.

\section{Rainfall characteristics.}

Mean rainfall for the 70 years period was $43842 \mathrm{~mm}$, maximum and minimum rainfall was recorded in 1961 and 1943 respectively, with a coefficient of variation of $7.23 \%$. Cycles are observed in rainfall patterns in Uganda for the period 1940 - 2009. Data shows decades of normal and beyond normal rainfall (Fig. 3) during the period of analysis. Three long spans of below normal rain are evident in the 1940s, 1960/70 and 1980s. Other particularly wet periods were experienced in early 1950s, 1960s, late 1970s and the 1990s (Fig.3). The contributing factors to the below average annual total rainfall for Uganda have not been established in this study despite the 1980s being drought years which had consequences on food security for the continent (Hulme 1992). The plots shows that very high rainfall totals in early 1960s and late 1970s were preceded by relatively low rainfall in Uganda (Fig.3).

Average seasonal cycle in precipitation rate from station data for 1940- 2009 over seven subbasins in Uganda are shown in Figure 4. It can be seen that there is a marked contrast in seasonal cycle between sub-basins that lie over and below latitude $2^{0} \mathrm{~N}$ (i.e northern and southern subbasins). According to Black et al. (2003) this contrast is evidence that reflects a strong influence of the southwest monsoon circulation on rainfall in East Africa. The other basins depict low amounts of rain during the southwest monsoon and show a semi-annual distribution of rainfall, which is characteristic of the equatorial zone.

Mean rainfall. Calculations for station means reveal that Entebbe international Airport recorded the highest mean annual rainfall $(1617 \mathrm{~mm})$ followed by Gulu meteorological station $(1559 \mathrm{~mm})$ during the time of analysis. On the other hand, Kangole station shows the lowest mean rainfall $(660 \mathrm{~mm})$ followed by Kotido $(677 \mathrm{~mm})($ Table 1$)$. These two stations with low rainfall lie within the Lake Kyoga sub basin in the far north east of Uganda (Figure 1). It is also revealed that, 8 stations (Morulem, Kawanda, Kijura, Nebbi, Tororo, Mutai, Kangole, Kibale) had their highest rains recorded in 1961. Six of these stations are within Kyoga sub-basin. Literature has indicated that the 1960s were times of high rains (Nicholson 1996, Kizza et al. 2009). Overall 12 stations recorded very high rainfall in the 1960s (Table 1). Six stations (Rwashamaire, Mbarara, Kamenyamigo, Rwoho forest station, Moyo and Mbale) also had their highest rains come in 1951(Table 1). Four of these stations are located in the Lake Victoria sub basin, and specifically lie within, what is often referred to as' the dry corridor of Uganda'. This area lies within the rain 
shadow of the western highlands shielding it from the winds from the Congo basin and also far from the reach of the southeast monsoon winds. These wind types have been identified to be influential in the distribution of rainfall in Uganda (Basarilwa 1995). Their mean annual rainfall ranges between $985 \mathrm{~mm}$ at Rwoho to $1025 \mathrm{~mm}$ at Rwashamaire, and their coefficient of variations ranging between $17 \%$ and $22 \%$. Mean annual rainfall for most of the stations under analysis exceeds $1200 \mathrm{~mm}$. Unlike, Nicholson (1996) the highest mean rainfall during the period of analysis is recorded around the lakes.

Coefficient of variation. Interannual variability according to Hulme (1992) is an important indicator of the reliability of the rainfall resource in Africa. Coefficients of variation for 36 stations have been computed in order to investigate the spatial pattern interannual variability of rainfall totals over Uganda.

The coefficient of variation defined as;

$$
C V=\left(\sigma_{s} / \overline{R_{s}}\right) 100(\text { percent })
$$

where $\overline{R_{s}}$ is the long-term mean annual rainfall and $\sigma_{s}$ is the standard deviation of annual rainfall totals for station $s$ (Türkeş, 1996) is used to represent changes in reliability. Figure 5 presents this measure of annual rainfall variability change over Uganda. Annual rainfall coefficient of variation for the stations in sub-basins is in the range of $13 \%$ to $29 \%$ (Table 1). High variations are exhibited at Kakooge, Kotido and Kangole, while Aduku variety, Kirima Forest station, Masindi Meteorological station and Ngetta Farm station showed the lowest variation in rainfall (Figure 5). As observed by Türkeş (1996) areas with coefficients over 20\% are likely to have more frequent and severe droughts because of the low reliability of the normal rainfall. Low values of coefficients imply high rainfall reliability. Sub-basin analysis indicates that, the coefficients of variation are low (average of 14.8\%) in Lake Edward sub-basin compared to other sub-basins, which show a dependable rainfall distribution. Further analysis indicates that rainfall for example at Kakooge has varied more in the last 30 years(1980-2009) than in the first normal (1940- 1969) implying that this station is likely to have more droughts in the future. It is also evident from the map that variability is not coherent, thus the causes of variability are not uniform (the variability is also dependent on e.g., the number of stations used, the interpolation scheme and the topography of the area)

Variations in Sub-basin normalized rainfall series. Before using the sub-basin normalized series for further analysis, the variance analysis was applied to regional data in order to assess whether the series adequately represent the region as a whole. Using the ratios of the variance estimates in time to the variance estimates in the area, it is apparent that all area-averaged rainfall anomalies have coherence in rainfall fluctuations (results not shown). An F- test helps to assess the relative importance of the two components of variance (Nicholson 1986). In most cases according to Nicholson (1986), the limiting value for the 0.01 probability level is about 1.50 or lower. Results from the analysis show that majority of the series had values exceeding 1.50 , meaning that there is a $1 \%$ probability that most of the temporal variance in the sub-basin can be accounted for by random fluctuations at a few stations.

Characterizing monthly rainfall. The concentration of the rainfall in a year is an important aspect of climate. Simply because when rainfall distribution is not balanced, it makes water resources 
planning, plant and crop growth difficult. It is therefore important to investigate rainfall concentration needs using a statistical derived index known as (PCI) that quantifies the relative distribution of the rainfall patterns. Based on Michiels et al (1992) approach, two different calculations procedures were used for deriving the PCI. In the first procedure, the mean monthly rainfall data set was estimated by averaging the monthly rainfall data over a number of years; afterwards a PCI was calculated (here referred to as Seasonal concentration). In the second procedure, PCI was calculated from rainfall totals of individual years (here referred to as temporal concentration). The PCI permits grouping of data sets according to the derived value. A PCI of less than 10 suggests a uniform distribution, a value from 11-15 denotes a moderate seasonal distribution, a value from 16-20 denotes a seasonal distribution (Michiels et al. 1992). An index above 20 represents strong seasonal effects, with increasing values indicating increasing monthly rainfall concentration.

>>> Table 2 here

The application of the first procedure based on the mean monthly rainfall data sets of the seven sub-basins (Table 2) results in a PCI, above 10 for Albert Nile and Aswa. This value suggests a uniform to moderate seasonal distribution of rainfall in the northern sub-basins of Uganda. The other 5 sub basins reveal a PCI below 10, suggesting a uniform seasonal rainfall. Temporal analysis for all stations has PCI values, which are below 10, which indicate a uniform concentration of rainfall for the years under analysis. The annual PCIs calculated for individual years are small compared to seasonal concentration index. Because the monthly rainfall of individual years deviates from the long term mean monthly rainfall. Higher values for temporal concentration of rainfall for individual years can also be due to seasonal concentration of the rainfall or to and random deviation from the long term mean monthly rainfall (Michiels et al. 1992). Further analysis at 30 year normal (1940-1969) and (1970-1999) also reveals the same pattern, which, further implies that the distribution of rainfall in the sub-basins has not changed with time (Table 2).

Since the PCI, like other statistical indices, does not reveal the actual month or season of maximum or minimum rainfall, the examination of sub-basin data set is necessary to identify the period of month (season) with maximum (minimum) rainfall, if there is any.

Figure 6 demonstrates that there is not a single month without rainfall, which is consistent with the uniform to moderate seasonal distribution derived from the PCI. From the analysis one can conclude from the shape of the mean monthly rainfall plots that rainfall distribution is bi-modal in 4 of the sub-basins; Lake Albert, Lake Edward, Lake Victoria, Victoria Nile located in the west and central part of Uganda and unimodal in the two sub-basins (River Aswa, Albert Nile) which are located in the Northern part of Uganda. Lake Kyoga sub-basin in the central and extending to the east of Uganda, gives a different picture of a well spread distribution of rainfall for a period of 9 months (March to November). The plot indicates two peak periods of rainfall in April/may and August/September. This is evidence of a transition zone between the northern and southern sub-basins. Such a trend could also be attributed to the merging of stations to derive an area-averaged series.

Maximum rainfall in the 4 sub-basins, which experience a bi-modal distribution pattern, is recorded in the MAM and SON seasons. In July and August the 4 sub-basins recorded low rainfall. Lake Kyoga sub-basin on the other hand, indicates low rainfall during the months of 
December to February. Peak rainfall for the northern sub-basins (River Aswa and Albert Nile) is in August (Figure 6). This kind of rainfall pattern over Uganda is related to the movement of (ITCZ), which brings rainfall approximately 1 month after the sun's path resulting in a bi-modal rainfall pattern, with the primary rain season occurring in March - May, and a shorter secondary rainy season occurring in October - December (Nicholson 1996, Kizza et al. 2009). Phillips and Mcintyre (2000) attribute moisture during the OND to the north easterly winds originating in the Indian Ocean. While the northern sub-basins which have peaks in August receive moisture from the Congo/Zaire basin to the southwest.

Visual inspection of plots in figure 6 inspired us to examine the contribution of each month to the annual total rainfall in the 7 sub-basins, expressed as a percentage. Five of the sub-basins show that April contributes the highest percentage of rainfall to the annual total received. While, two basins reveal that the biggest percentage of rain is received in August. The analysis also reaffirms that, central and southern sub-basins receive high percentage of rains in the MAM and SON seasons. The Albert Nile and River Aswa sub-basins have a longer wet season (April October) compared to the rest of the sub-basins. Further explanation underlying the general atmospheric circulation that accounts for the above rainfall patterns can be found in literature by (Ogallo 1993, Basalirwa 1995, Nicholson 1996).

Drought years from rainfall anomalies. Drought is a recurring extreme climate event over land characterised by below-normal precipitation over a period of several months to several years or even a few decades (Dai 2011). Drought years from annual and seasonal anomalies of the subbasins are identified in two climatic normal's i.e 1940 to 1969 and 1970 to 1999. Literature linked droughts and floods to El Niño/Southern Oscillation (ENSO), Indian Dipole and other large-scale climate system (Ogallo 1988, Nicholson 1996). The study indicates anomalous years that received below and above normal rainfall. The tendency for rainfall to be above average in most of the sub-basins during ENSO years and for drought to occur during the following year (Figure 8a-g) is also evident. We also investigated what Nicholson (1996) referred to as seasonal preference for the ENSO related rainfall anomalies. She noted that in east Africa, 'positive anomaly occurs during the short rains of ENSO year and the drought during the long rains of the following year. Our analysis reveals that, the 7 sub-basins experienced drought in the periods 1945/46, 1952-1954 and 1980-1984 (these are depicted in a Table not shown here). Using Nicholson, (1996) argument, the years 1942, 1952, 1958, 1964, 1969, 1973, 1979, 1983... should have been drought years. Using the percentage of normal from equation (9), Drought Severity Index (DSI), captures well, the predicted years among others (results not shown). Some of the years revealed by the analysis, were identified as La Niña years by (Phillips and Mcintyre 2000).

For the 30 year period (hereafter referred to as climatic normal) and for each season, the occurrences of drought across the respective sub-basins were also investigated. For example, 1943 and1949 appear as drought years for six sub-basins while 1952/53 appear in five subbasins. Further still, Albert Nile, Victoria Nile and Lake Victoria had similar drought years in the first climate normal (1940-1969), which is also reflected in the MAM rainfall seasons of Albert Nile and Victoria Nile Sub-basins. The three sub-basins have $62.4 \%$ of water resources when combined. Thus drought occurrence in these sub-basins in future can cause adverse effects on the water distribution with in the country. 
Mann-Kendall test. Seventeen precipitation variables (i.e 12 monthly totals, annual and seasonal series) were subjected to the Mann-Kendall test at each sub-basin (Table 3). Significant increasing trends at 0.05 level were revealed in January (14\%), October (57\%), November (43\%) and December (14\%). The other months showed increasing and decreasing trends, which were not statistically significant. The SON season on the hand had $43 \%$ increasing trends. The number of negative trends exceeded that of positive trends during April, May and August especially in the sub-basins that boarder with the Equator. This means that the sub-basins are experiencing a reduction in rainfall in the months that contribute the biggest percentage of rainfall. The continued reduction may affect the timing of agricultural activities in the sub-basins in the future.

Monthly total precipitation: During January, only positive trends are detected in all sub-basins. During February, four sub-basins to the north and west of Uganda show positive trend. Negative trends are observed in sub-basins found in central Uganda around Lake Victoria and the Victoria Nile. During March, the sense of trend is positive in the central, east and west and becomes negative for the northern sub-basins (Albert Nile and River Aswa). When it comes to April, the trend behaviour is mixed in such a way that decreasing trends are dominant, with occurrences around the north western, south western and central parts of Uganda. May has more occurrences of decreasing rainfall, with one sub-basin (Lake Edward) showing no trend. June shows mixed occurrences where four sub-basins have positive trends and the trends in the three sub-basins that form the Albert water management zone are decreasing. During July and August, five sub-basins demonstrate increase and decrease in rainfall respectively. Kyoga and Victoria Nile are subbasins that have shown a non-significant decrease in both months. September is one of those months whose results give mixed trend characteristics. Three of the sub-basins detected have experienced a decreasing trend from May to September when they hit a turning point and start to increase. During October, November and December (OND), homogeneity of direction across the country is detected, similar to what Nicholson (1996) found for most of eastern Africa. In October, four (River Aswa, Lake Albert, Lake Victoria and Victoria Nile) sub-basins; in November, three (River Aswa, Lake Albert and Lake Kyoga) sub-basins and in December, one (Albert Nile) sub-basin demonstrate significant trends at 0.05. Kizza et al (2009) also found positive trends in the short rains at most stations located in the northern part of the Victoria basin.

>>> Table 3 here

Climatic normal: To ascertain the changed behaviour of annual, seasonal and monthly rainfall we performed a trend analysis with in a climatic normal and the results are provided in Table 3. The analysis shows more positive trends in monthly rainfall totals especially in the second normal. Positive trends were dominant during the OND months and these were equally distributed in the first and second normal. Negative trends are prominent in January and August during the first normal (1940 to 1969). The rest of the months show mixed results of increasing and decreasing trends during the period of analysis. Significant trends for the first normal were evident in Victoria Nile during March, in Lake Edward during July, Lake Kyoga and Victoria Nile during August and Lake Albert sub-basin during November (Table 3). Six of the sub-basins experienced significant trends in October except Albert Nile sub-basin. On the other hand, the second normal showed significant negative trends in May and September for (River Aswa), October trends were positive for (Lake Albert and Lake Edward), and in December positive 
significant trends are evident for the Albert Nile, Lake Albert and Lake Kyoga sub-basins (Table $3)$.

Annual total precipitation: Figure 7 shows the spatial distribution of negative and positive trends for annual total rainfall. The majority of the sub-basins have positive trends which are non significant at 5\%. Sub-basins showing negative trends are Albert Nile and Lake Edward. From a regional perspective, the decreasing trends are observed in western and north western Uganda. The rest of the regions show an increase in annual total rainfall.

The time-series plots for Albert Nile sub-basin indicate a slight decrease in annual total rainfall with a low-frequency fluctuation (Fig. 8a). The normalized rainfall anomalies for Albert Nile sub-basin are characterised by four major wet periods, during the years of $1954-1958,1961$ 1964, 1976 -1979 and 1997- 1998, and three major dry periods, during the years of 1942 - 1944, $1966-1974$ and $1980-1994$ (Fig. 8a). The maximum and minimum rainfall was recorded in 1961 and 1971 respectively (Table 3).

The time series plot of River Aswa sub-basin (Fig. 8b) shows slightly a decreasing trend in annual rainfall with high interannual variability. Three notable periods, during the years of 1942 1945, 1952-1960 and 1964-1968 were dry. Almost all years with in the period 1952-1960 are characterized with negative rainfall anomalies. The wet periods were revealed in the years 19461951, 1961-1963, 1969-1972, 1976-1978, 1982-1984 with some dry breaks in between of one or two years. The maximal and minimal rainfall values were recorded in 1977 and 1953 respectively (Table 3 ).

The time-series plot of Lake Albert sub-basin (Fig. 8c) exhibit high frequency fluctuation. There was a major dry spell during the period 1942-1960. The situation however, reverses to shorter dry years than wet years during the period after 1960. The wettest and driest years were 1961 and 1983 respectively (Table 3 ).

The normalized rainfall anomalies of Lake Edward sub-basin show a high frequency about a decreasing long term mean (Fig. 8d). In spite of a spell of wet years during the period 19431945, 1974-1978, 1996-1998, one can also detect wet anomalies interspersed with short dry spells of 1 or 2 years, in the period 1954-1974. The sub-basin experienced two long dry periods between 1979-1986 and 1990-1995. Highest rainfall was recorded in 1996, while the lowest in 1965 (Table 3).

The time series plots of Lake Kyoga sub-basin show a slightly downward trend in annual rainfall with a weak frequency fluctuation (Fig. 8e). The sub-basin is characterised by three major dry periods, during the years 1942-1949, 1952-1959, and 1979-1981 and a wet period from 19611970, with the exception of two, one year dry breaks in 1965 and 1971 and two year dry break1975/76. After the 1997/98 wet spell (El-Nino years in Uganda), annual totals have continued to decline. Maximum rainfall was recorded in 1961 and minimum in 1980 (Table 3).

A snap short inspection of the time series plot of Lake Victoria sub-basin would give an impression that the normalized rainfall series have equal variation of wet and dry years (Fig. 8f). The frequency is apparently low, which tends towards a reduction in annual total rainfall. Subbasin total rainfall anomalies experienced four major wet conditions during the periods of 19611964, 1972-1978, 1987/88 and 1996/97, along with seven dry conditions during the periods of 
1940-1950, 1951-1954, 1958-1961, 1965-1971, 1980-1986, 1989-1993 and 2002-2005. The year 1951 is the wettest on the sub-basin record, with a positive anomaly of +48.4 , while 1952 was the driest with a negative anomaly of -33.3 .

The time series plots of the Victoria Nile sub-basin depict high frequency of variability (Fig. 8g). This is the only sub-basin that has equal periods of wet and dry years. Wet conditions dominate during the periods of 1940-1942, 1951, 1960-1964, 1977-1979, 1987/88, 1996-1999 and $2006 / 07$, with the highest wet anomaly in 1961, where as dry conditions occur during the periods of 1943-1950, 1952-1954, 1968-1972,1980-1986, 1989-1995,2004/05 and 2008. The year of 1983 is the driest of the sub basin annual series, with a high negative anomaly of -28.5 .

A closer inspection of the above plots (Fig.8a-g) reveals consistence in what is found in literature. For example annual series plots above indicate dry conditions in the 1950s and wet conditions in the 1960s. Analysis also shows that, sub-basins like; Albert Nile, River Aswa, Lake Albert, Lake Edward \& George, Lake Kyoga, and Kafu-Victoria Nile recorded their highest rainfall in 1961 and 1977. These sub-basins were affected by the incursion of humid Congo air, which according to Anyamba, 1984 played a role in the 1961/62 floods (Nicholson 1996). This study has found out that, dry conditions existed in the early 1980s, 1990s and relatively wet conditions were experienced in the late 1990s (Fig. 8a-g).

Seasonal trends. Inspection of the map patterns in (Fig.9a-d) and Table 3 reveals an interesting pattern of trend in the seasonal distribution of rainfall. For instance DJF season has positive trends in all sub-basins, although none of the trends is statistically significant at 0.05(Fig.9a). The respective slopes of change are also negligible, where the highest is 0.11 in Victoria Nile sub-basin ((Table 3). MAM season, a period which contributes high percentage of rainfall (Fig.9b) revealed mixed trends of decrease and increase which are not statistically significant at 0.05 . Four of the sub-basins exhibit positive trends and the three show negative trends. These results are consistent with what Nyenje and Batelaan (2009) found out in their study. They predict a general increase in rainfall, with the greatest increase expected in the wet seasons (MAM and OND). Unlike the rest of the seasons, JJA has more negative trends than positives with slope changes that are negligible (Table 3). A positive trend has been recorded in the River Aswa sub-basin during the JJA season (Fig.9c). Maximum and minimum rainfall was recorded in 1946 and 1959 at this basin respectively.

Rainfall trend in the SON season are positive for all sub-basins (Fig.9d), with slope changes that are negligible. This is the only season where positive and statistically significant trends at 0.05 , significance level have been revealed at Lake Albert, Lake Victoria and Victoria Nile sub-basins (Table 3). Most of the high rains were recorded in 1961 for five of the sub-basins with the exception of two; River Aswa for 1983 and Lake Edward and George for 1996 during the period of analysis. Literature and analysis identify SON as the second wet season which contributes greatly to the total annual rainfall in the seven sub-basins. Down scaled data predicts rainfall increase in this season by over $30 \%$, in the 2020 s,over $80 \%$ in the 2050 s and over $100 \%$ in the 2080s (Nyenje and Batelaan 2009). Three years; 1941, 1951, and 1957 which appear in (Nicholson 1996, Phillips and Mcintyre 2000) have also been detected in the sub-basins series, as wet years in the scope of analysis.

Trend analysis shows that the only months in which significant rainfall occurs throughout the analysis period are OND. It is also identified that the climatological seasons are DJF, MAM, 
JJA, and SON. The means of these periods are depicted in Fig. 6. Coefficients of correlations between annual and seasonal rainfall departure series for individual sub-basins are presented in table 4. Correlations between annual totals and MAM exceed 0.5 for nearly all sub-basins except for Lake Albert sub-basin whose correlations were 0.2. Correlations for SON are above 0.4 and the highest is 0.7 for Lake Edward basin. The correlations are somewhat higher for 4 sub-basins that cover an extensive area in Uganda during the DJF season. The Albert Nile, River Aswa and Lake Edward sub-basins depict correlations above 0.5, while the other 4 have low correlations (Table 4) during JJA season. Since the three sub-basins have peak rains in August relative to others (Fig. 6a, b, and e) is evidence to support the argument that some parts of the country receive moisture from the Congo/Zaire basin to the west (Ogallo 1988, Phillips and Mcintyre 2000)

>> Table 4 here

Sen's $T$ test. The Sen's T test results indicate negative trend in six of the sub-basins. The subbasins that detected negative trends are Albert Nile, River Aswa, Lake Albert, Lake Edward, Lake Kyoga and Lake Victoria. Significant decreasing trends were observed in River Aswa and Lake Albert sub-basins. Results for Victoria Nile sub-basin show a positive trend, which is not statistically significant at 0.05 . Results are summarised in table 3 .

Sen's estimator. The Sen's slopes $\left(\mathrm{Q}_{\mathrm{i}}\right)$ of all trends in rainfall for the sub-basins are presented in table 3, for three periods; 1940-2009 and for the two normals (1940-1969, 1970-1999). They indicate change per unit time of the trends detected monthly, annually and seasonally. Results do not reveal any slope that is statistically significant. It has also been presented that slopes for DJF are positive for all sub basins while those of JJA are negative with the exception of Albert Nile and River Aswa. The rest of the seasons across all sub-basins show slopes with mixed signs. The positive change in the DJF can be attributed to increase in rainfall in December and January. The other months that showed positivity are November and December, with slopes, which were higher in the second climatic normal. However, all these magnitudes of change in all sub-basins are not statistically significant at 0.05 . Seasonal slopes for the sub-basins indicate that, magnitude of change was higher in the first normal (1940-1969) than those calculated for the second normal, except for the JJA season in Victoria sub-basin.

\section{Discussion and summary}

Conclusions from understanding of the nature of rainfall can be applied to various social and economic spheres to support decision making related to water resources for urban and industrial use, energy planning, tourism, commercial activities and protection of the environment and agricultural production (Sinoga et al. 2011). These aspects of the local environment conditions, natural resources and social-economic activities are closely linked. For example, when rains were late and early rains were poor in the East African region in 2010, it created a situation of food insecurity in the region (MOFPED 2011), resulting into hyper-inflation among other factors. But Literature on Uganda's rainfall is scarce and where it is available it is on a smallscale analysis or in less detail with in East African discussions. As a starting point to help in the 
decision-making process on water resources availability, the increasing need to know the precipitation behaviour and trends justifies the present work, in a water resource rich country like Uganda.

A study by Guijarro (2002 in Sinoga et al. 2011) warns of the tendency of increased spatialtemporal variability in seasonal precipitation and the low statistical significances occasionally found (as a result of the high variability in rainfall) that can lead to underestimating the importance of these precipitation trends. If such trends continue in the sub-basins studied there will be major changes in distribution of water resources, which are critical for economic activities like tourism, energy, industry and agriculture.

Starting out from a wide base of 36 observatories, with homogeneous data and quality contrast, the precipitation trends and the spatial patterns of its evolution in time have been analysed for 1940-2009. Analysis shows decades of normal and beyond normal rainfall, with a marked contrast in seasonal cycles with in sub-basins. Mean annual rainfall is seasonal with much of the rainfall measured during March to May, and although no significant change in annual rainfall can be discerned in Uganda an increase in the variability in the distribution of monthly rainfall can be seen. Variations in annual rainfall are relatively low which imply a dependable rainfall distribution. Plots also indicate that, no single month in Uganda goes without rainfall in the subbasins. Sub-basins in the north have a unimodal type of rainfall distribution while those in the south have a bimodal distribution with maximums in July to August and March to May respectively. The DSI used in the study informs us of the drought years during the analysis period, which was consistent with previous literature.

From the monthly rainfall variables, October, November, December and January were found to have significant increasing trends as opposed to other months showing positive or negative trend with in the main drainage sub-basins in Uganda. The result of trend analysis of monthly total rainfall especially in October and November is reflected in the SON season, but not in the annual series. There were downward trends in the annual rainfall series, predominantly in north western and south western of Uganda, while the rest of the sub-basins had upward trends.

Results could have considerable implications for society and the economy. Decrease in inland precipitation will cause problems. This is because the reservoirs controlling and storing water resources are located in the north eastern (Aswa/Kyoga) part of the study region, and a decrease in precipitation in this area could reduce water reserves. These reservoirs (Valley dams) supply water to the pastoralists in times of drought. Studies of trends in rainfall and its evolution provide useful tools for managers and administrators of water resources, especially in areas where periods of droughts can result in major economic losses, and social and political conflict.

Water is probably the country's most abundant resource, and therefore it seems to attract less attention, but if water demand increases and pessimistic predictions about climate change come true then adverse effects have to be faced. These will require efficient water policy actions with in a high degree of hydrological planning that demands appropriate infrastructures and a rational use of the resource.

It is worthwhile emphasizing that the trend results presented in this study were not sufficient to approve climatic change in the main drainage sub-basins of Uganda. Future studies are needed to 
address the issue of trend attribution and to attempt to establish a linkage between climatic change and the observed hydrologic trends.

\section{References}

Asadullah, A, Mcintyre, N, Kigobe, M., 2008. Evaluation of five satellite products for estimation of rainfall over Uganda. Hydrological Sciences Journal, 53 (6), 1137-1150.

Awange, J.P, Ogalo, L, Bae K-H, Were, P, Omondi, P, Omute, P, Omullo, M., 2008. Falling Lake Victoria water levels: Is climate a contributing factor? Climatic change.89, 281-297.

Basalirwa, C.P.K., 1995. Delineation of Uganda into climatological rainfall zones using the method of principal component analysis. International Journal of Climatology, 15, 1161 -1177.

Black, E, Slingo J., 2003. An observational study of the relationship between excessively strong short rains in coastal East Africa and Indian ocean SST. Monthly weather review.131, 74 - 94.

Ceballos, A, Martinez-Fernandez, Luengo-Ugidos, M.A., 2004. Analysis of rainfall trends and dry periods on a pluviometric gradient representative of Mediterranean climate in the Duero basin, Spain. Journal of Arid Environments, 58: 214 -232.

Conway, D., 2005. From headwater tributaries to international river: Observing and adapting to climate variability and change in the Nile basin. Global environmental change, 15, 99-114.

Co-operative Research Centre for Catchment Hydrology (CRCCH)., 2005. TREND User Guide. p 17.

Dai A., 2011. Characteristics and trends in various forms of Palmer drought severity index during 1900 -2008. Journal of Geophysical research, 116, D12115, doi:10.1029/2010JD015541, 2011.

de Lima, M.I.P, Carvalho S.C.P, de Lima, J.L.M.P, Coelho, M.F.E.S., 2010. Trends in precipitation: analysis of long annual and monthly time series from mainland Portugal. Advances in Geosciences, 25,155-160.

De Luis, M, Raventos, j, Gonzalez-Hidalgo, Sanchez, J.R, Cortina, J., 2000. Spatial analysis of rainfall trends in the region of Valencia (East Spain), International Journal of Climatology 20,145-149.

GOU., 2007. Climatic change: National adaptation plan action. Ministry of water and Environment. Kampala. Uganda.

Hirsch, R.M, Slack, J.R., 1984. Non-parametric trend test for seasonal data with serial dependence. Water resources research, 20, (4), 727-732.

Hulme, M., 1992. Rainfall changes in Africa: 1931- 1960 to 1961-1990. International Journal of Climatology, 12, 685-699. 
Kampata, J.M, Parida B.P, Moalafhi, D.B 2008. Trend analysis of rainfall in the headstreams of the Zambezi River Basin in Zambia. Physics and Chemistry of the Earth, 33, 621-625.

Kizza, M, Rhode, A, Xu, Y. C, Ntale H. K, Halldin, S., 2009. Temporal rainfall variability in the Lake Victoria Basin in East Africa during the twentieth century. Theoretical and Applied Climatology, 98, $119-135$.

Kothyari U.C., Singh V.P (1996) Rainfall and temperature trends in India. Hydrological processes. 10: 357 - 372 .

Kraus, E.B., 1977. Subtropical droughts and Cross-Equatorial energy transports. Monthly weather review, 105, 1009 - 1017.

Lopez-Moreno, J.I, Vicente-Serrano, S.M, Angulo-Martinez,M, Begueria, S, Kenawy, A., 2009 Trends in daily precipitation on the northeastern Iberian peninsula 1955-2006. International Journal of Climatology, 30, 1026 - 1041.

Michiels, P, Gabriels, D, Hartmann, R.,1992. Using the seasonal and temporal precipitation concentration index for characterizing the monthly rainfall distribution in Spain. Catena, 19, 4358.

MOFPED., 2011. Annual economic performance report 2010/11. Directorate of economic affairs, Ministry of Finance, Planning and economic Development. December 2011. Kampala Uganda.

NARO (National Agriculture Research Organisation)., 2001 Agriculture in Uganda. Vol.1. General information. Fountain publishers' ltd. ISBN 9789970022434.

NEMA (National Environment Management Authority) (2008) State of Environment Report for Uganda, 2008. NEMA, Kampala, Uganda.

Ngongondo, C. S., 2006. An analysis of long-term rainfall variability, trends and ground water availability in the Mulunguzi river catchment area, Zomba mountain, southern Malawi. Quaternary international, 148, 45-50.

Nicholson, S.E., 1986. The nature of rainfall variability in Africa south of the equator. International Journal of Climatology, 6, 515-530.

Nicholson, S.E., 1996. A review of climate dynamics and climate variability in Eastern Africa, in Johnson, T.C, Odada, E (eds), The limnology, climatology and paleoclimatology of East African lakes. Gordon and Breach. Amsterdam, pp 25 -56.

Nsubuga, F.W.N, Olwoch, J.M, Rautenbach, C.J., 2011. Climatic trends at Namulonge in Uganda: 1947- 2009. Journal of Geography and Geology, 3,119 -131.

Nyenje, P.M, Batelaan, O., 2009. Estimating the effects of climate change on groundwater recharge and baseflow in the upper Ssezibwa catchment, Uganda. Hydrological Sciencesjournal, 54(4), 713 - 726. 
Ogallo, L.A (1993) Dynamics of the East African climate. Proceedings of Indian Academy of science(Earth Planet. Sci.i.) 102 (1) 203 -217.

Ogallo, L.J., 1988. Relationships between seasonal rainfall in East Africa and the southern oscillation. International Journal of Climatology, 8, 31-43.

Partal, T, Kahya, E., (2006) Trend analysis in Turkish precipitation data. Hydrological processes, 20, 2011-2026.

Patra, J.P, Mishra, A, Singh, R, Raghuwanshi, N.S., 2011. Detecting rainfall trends in twentieth century (1871-2006) over Orissa State, India. Climatic change. DOI 10.1007/s10584-011-02155 .

Phillips, J, Mcintyre, B., 2000. Enso and inter-annual rainfall variability in Uganda: Implications for agricultural management. International Journal of Climatology,20,171-182.

Rai, R.K, Upadhyay, A, Ojha, C.S.P., 2010. Temporal variability of climatic parameters of Yamuna river basin: Spatial analysis of persistence, trend and periodicity. The open hydrology journal, 4, 184-210.

Shahid, S, Khairulmaini, O.S., 2009. Spatio-Temporal Variability of Rainfall over Bangladesh during the time period 1969-2003. Asia-Pacific of Atmospheric sciences, 45(3), 375-389.

Sinoga, J.DR, Marin, R.G, Murillo, J.F.M, Galeote, M.A.G., 2011. Precipitation dynamics in southern Spain: trends and cycles. International Journal of Climatology.31, 2281-2289.

Türkeş, M., 1996. Spatial and temporal analysis of annual rainfall variation in Turkey. International Journal of Climatology, 16, 1057- 1076.

UNWDR., 2005. Uganda National Water Development Report 2005. Ministry of water and Environment. Kampala, Uganda.

Yue, S, Pilon, P, Phinney, B, Cavadias, G., 2002. The influence of autocorrelation on the ability to detect trend in hydrological series. Hydrological processes, 16, 1807- 1829.

Yue, S, Hashino, M., 2003. Long term trends of annual and monthly precipitation in Japan. Journal of the American water resources association,587- 596.

Zhang, X, Vincent, L.A, Hogg, W.D, Niitso, A., 2000. Temperature and precipitation trends in Canada during the $20^{\text {th }}$ century. Atmospheric Ocean, 38, $395-429$.

Zhao, C, Ding, Y, Ye, B, Yao, S, Zhao, Q, Wang, Z, Wang, Y., 2011. An analyses of long-term precipitation variability based on entropy over Xinjiang, north western China. Hydrology and Earth System Science Discussion, 8, 2975- 2999. 


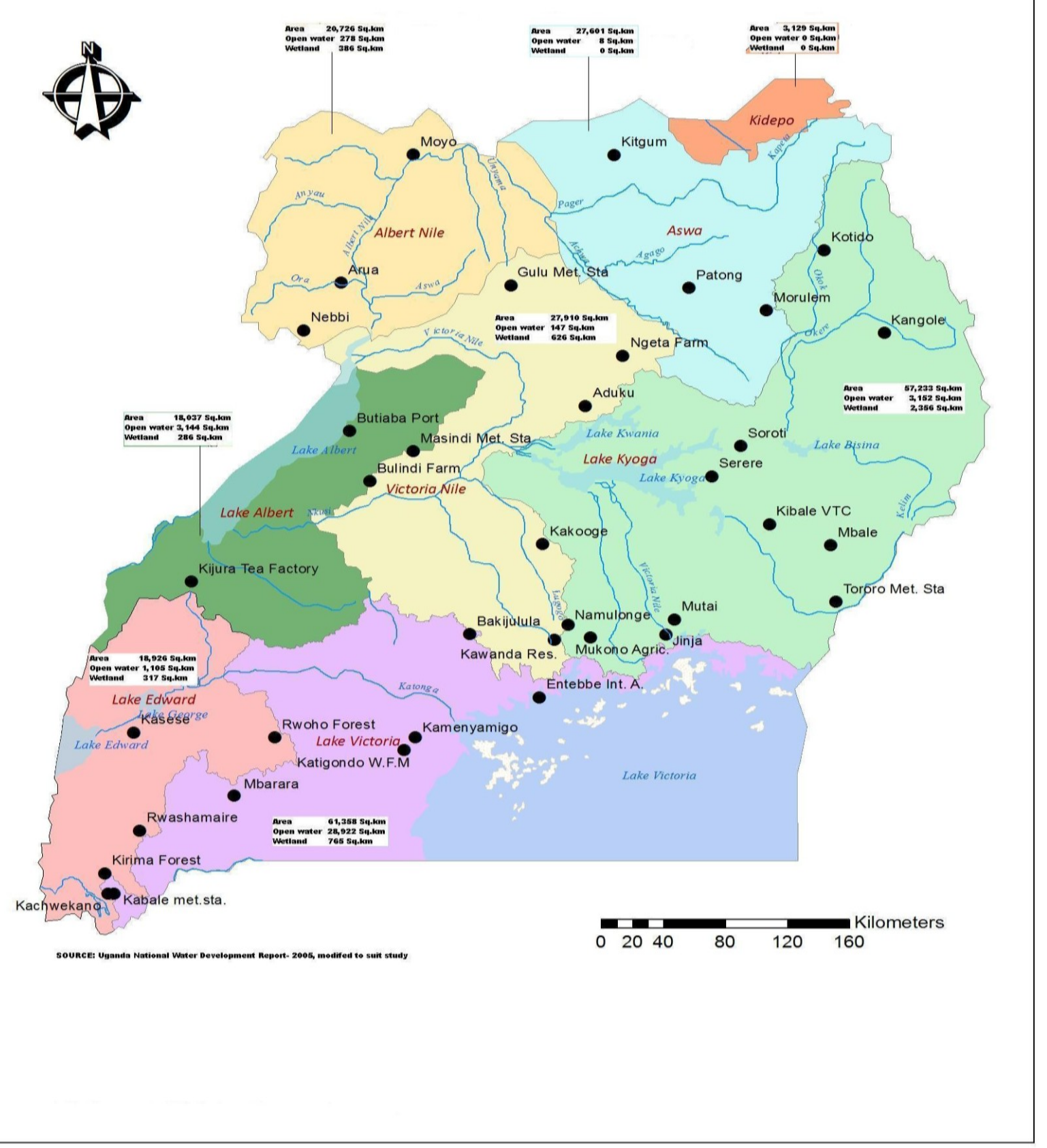


Figure 1 shows the distribution of observatories and the size of the main drainage sub-basins of Uganda.

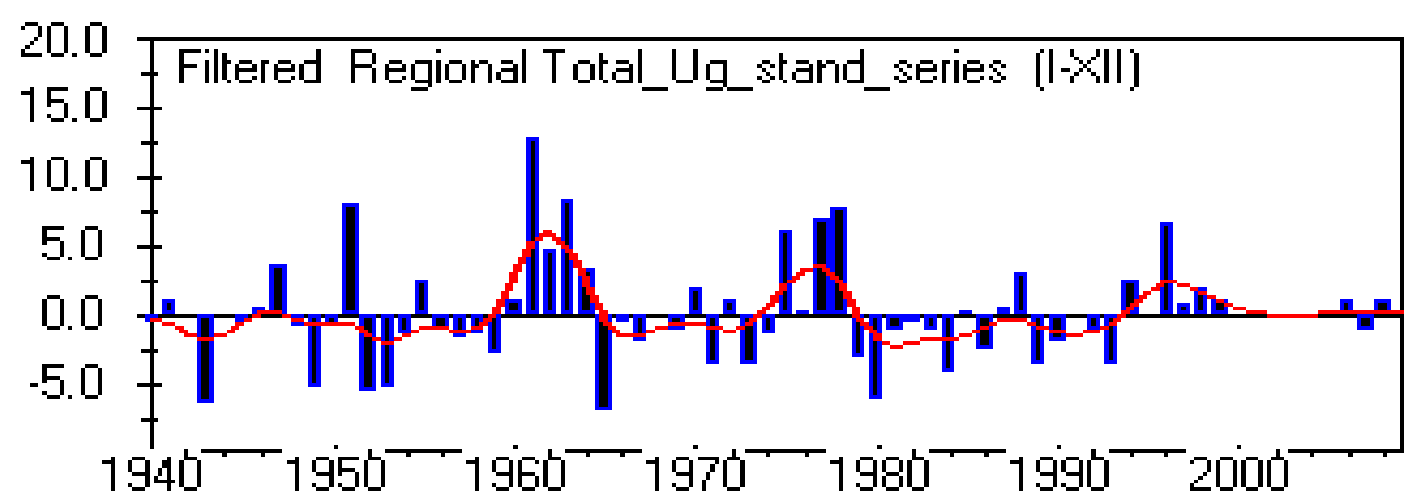

Figure 3 Regional total rainfall (mm) for the period $1940-2009$.

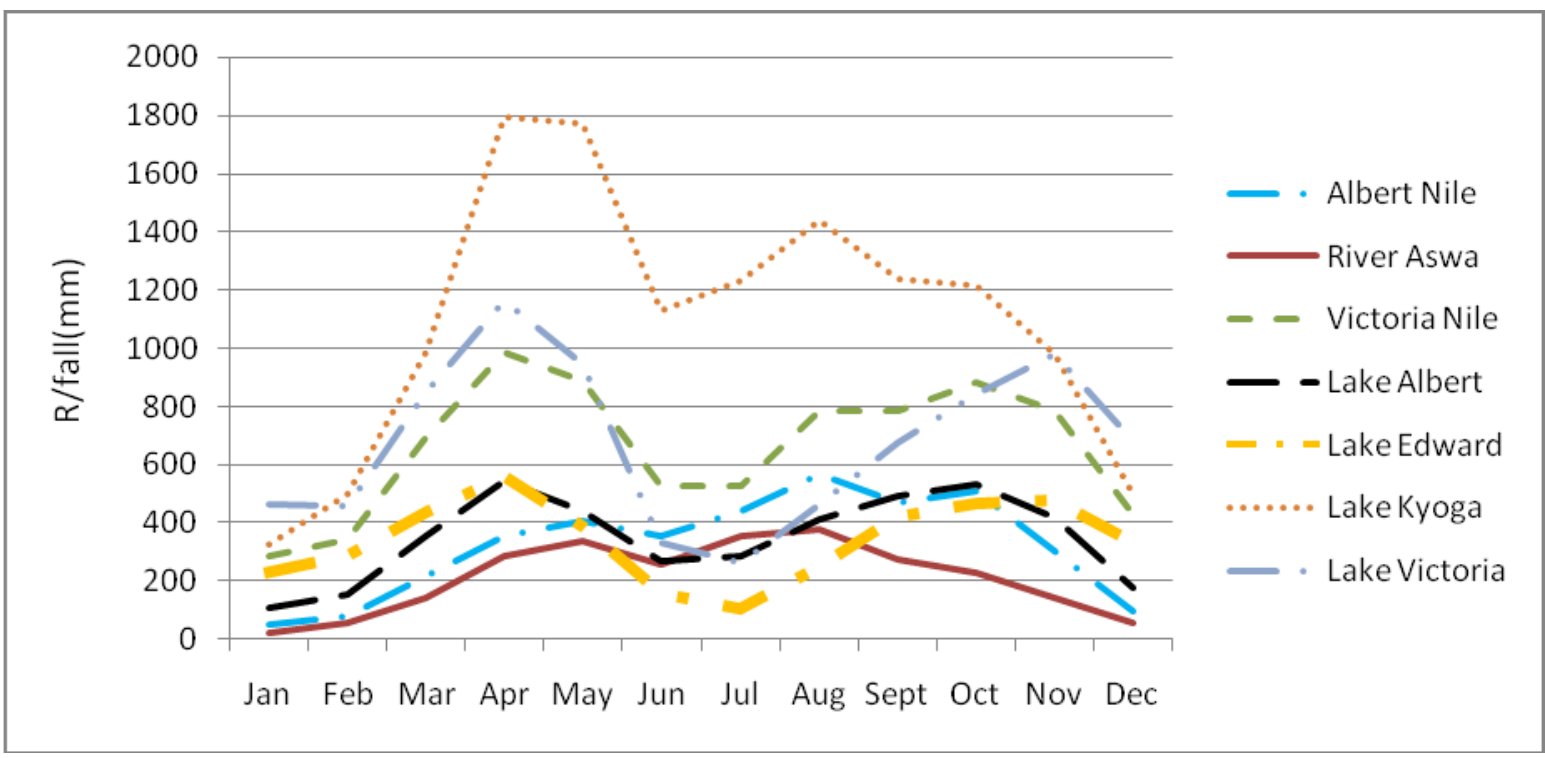

Figure 4 Seasonal cycle in Ugandan rainfall between the seven sub-basins. 


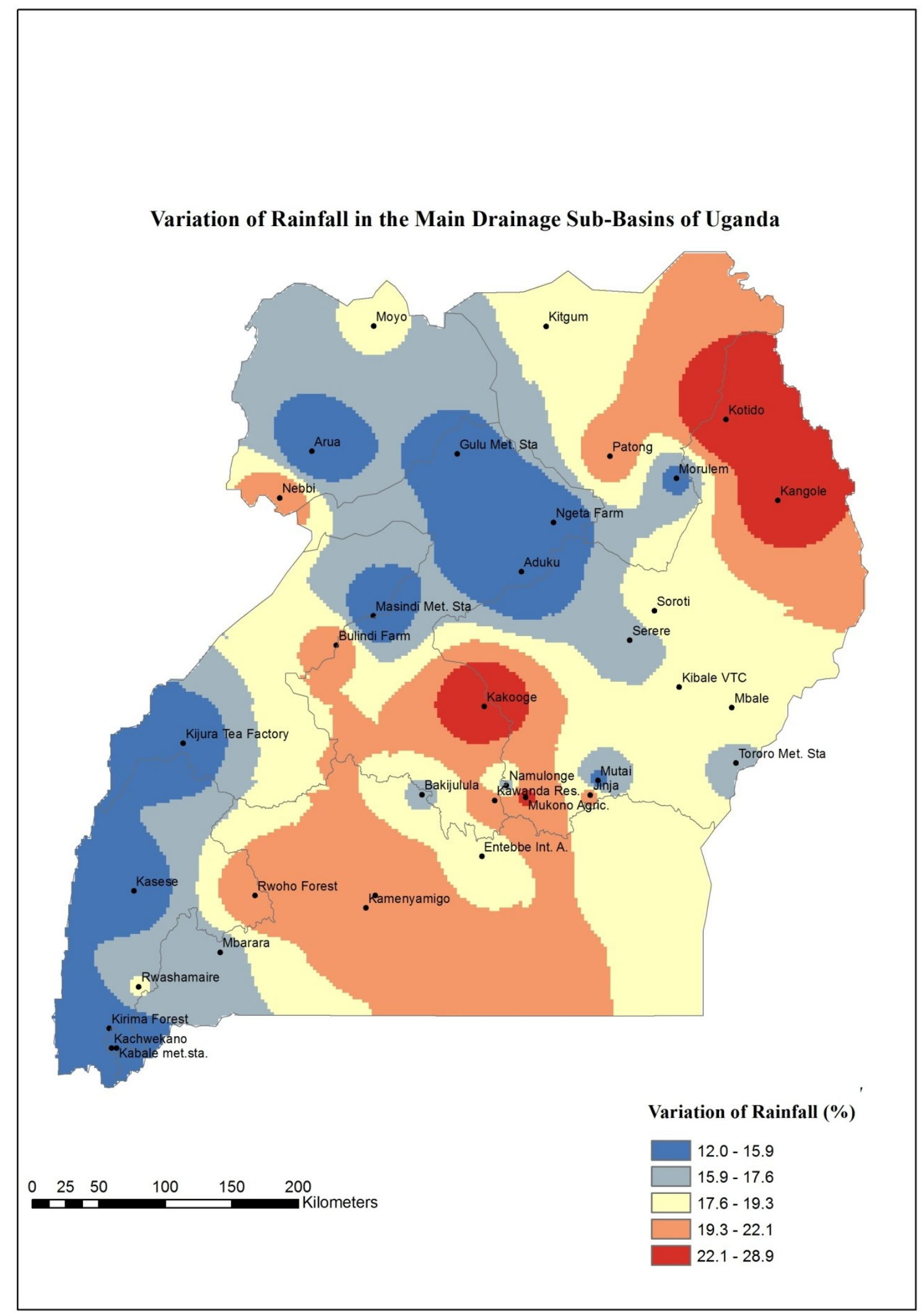

Figure 5 Variation of rainfall in the main drainage Sub-basins in Uganda 1940 - 2009. Variability is expressed as percentage of coefficient of variation at rainfall stations. 


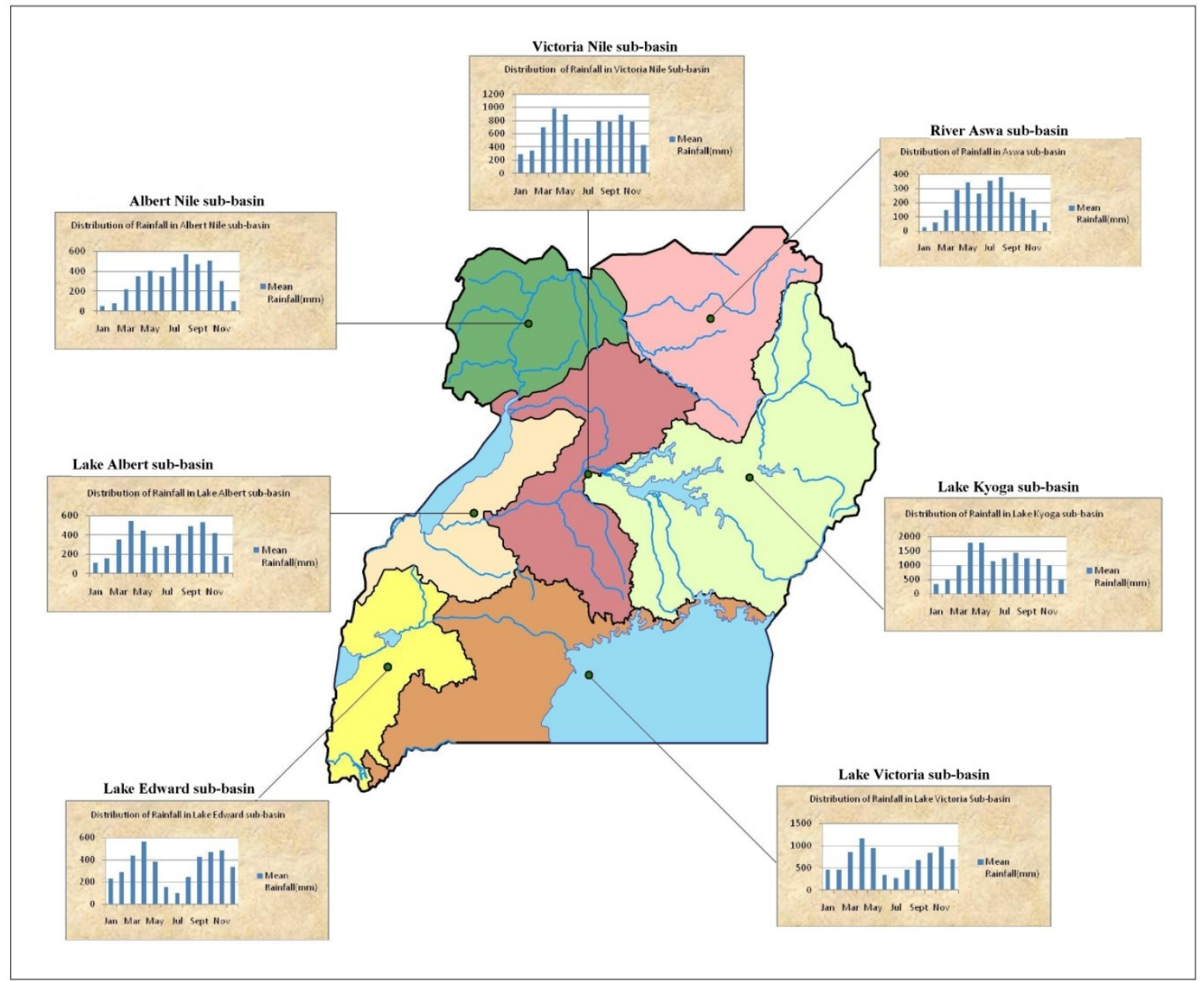

Figure 6 Distribution of long term mean monthly rainfall ( $\mathrm{mm}$ ) in the sub-basins of Uganda from $1940-2009$. 


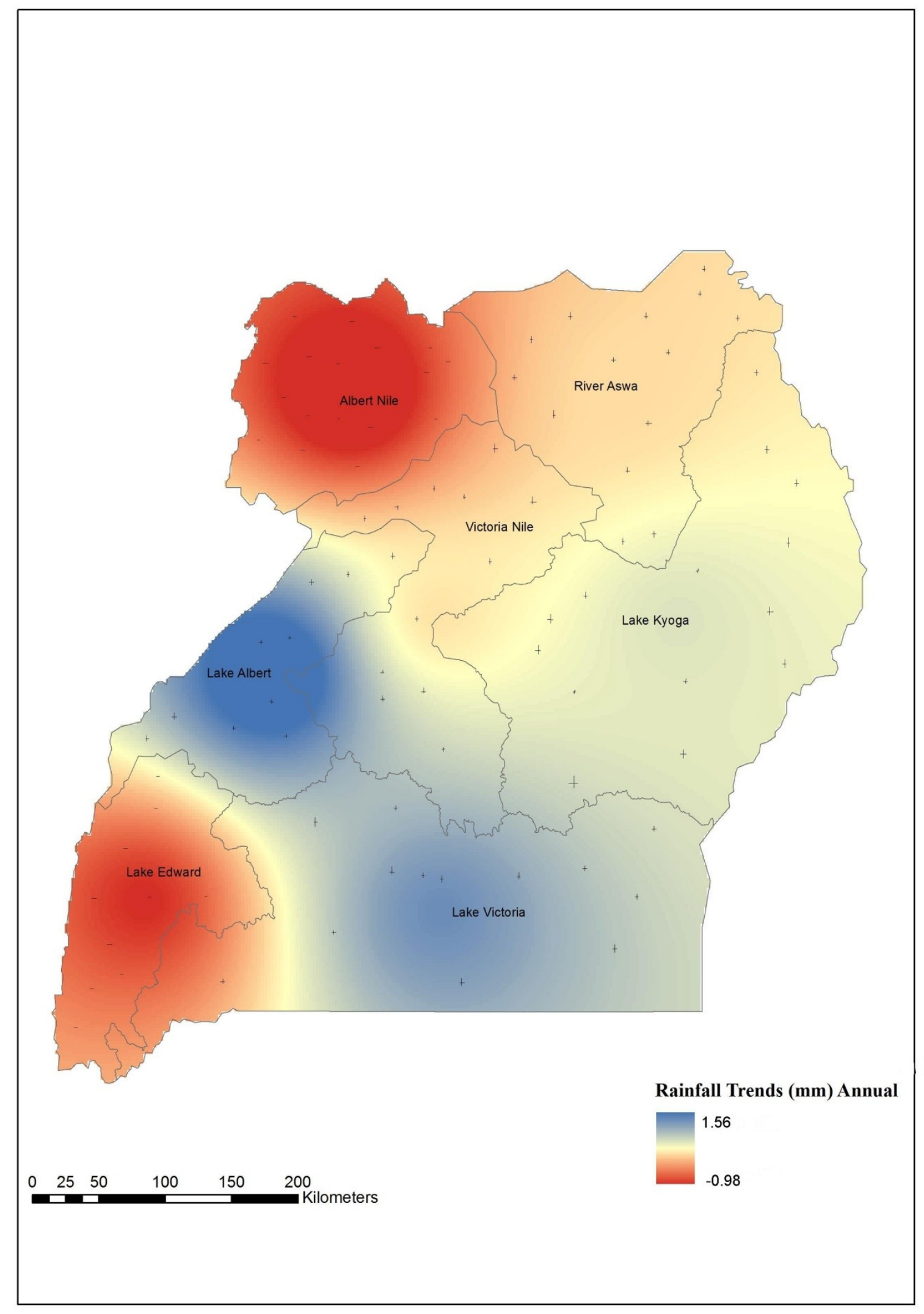


Figure 7 shows the spatial distribution of negative (-) and positive (+) trends for annual total rainfall in Uganda's main drainage Sub- basins.

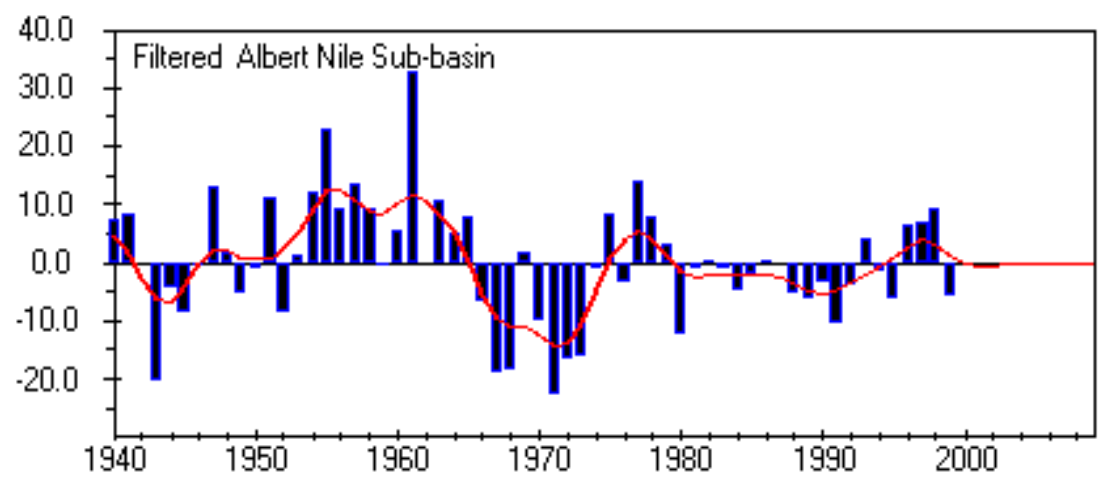

a)

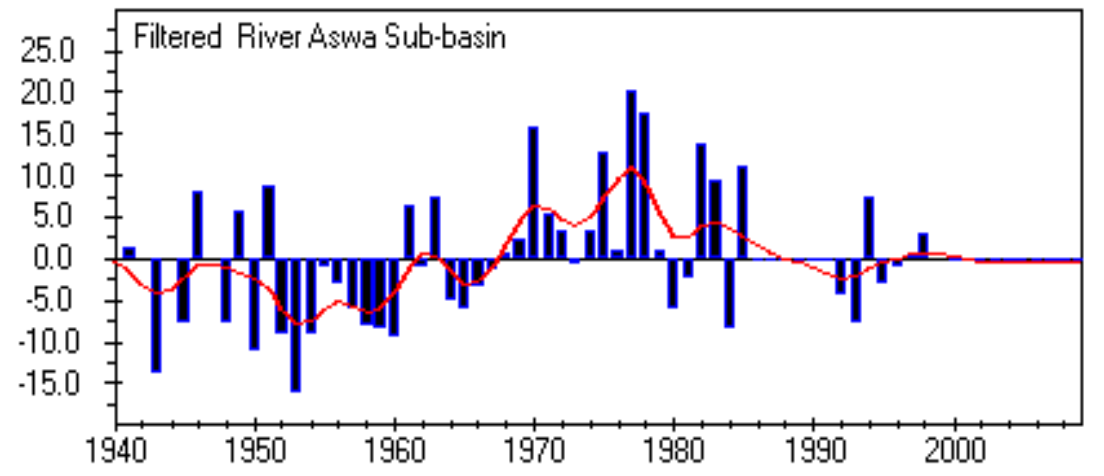

b) 


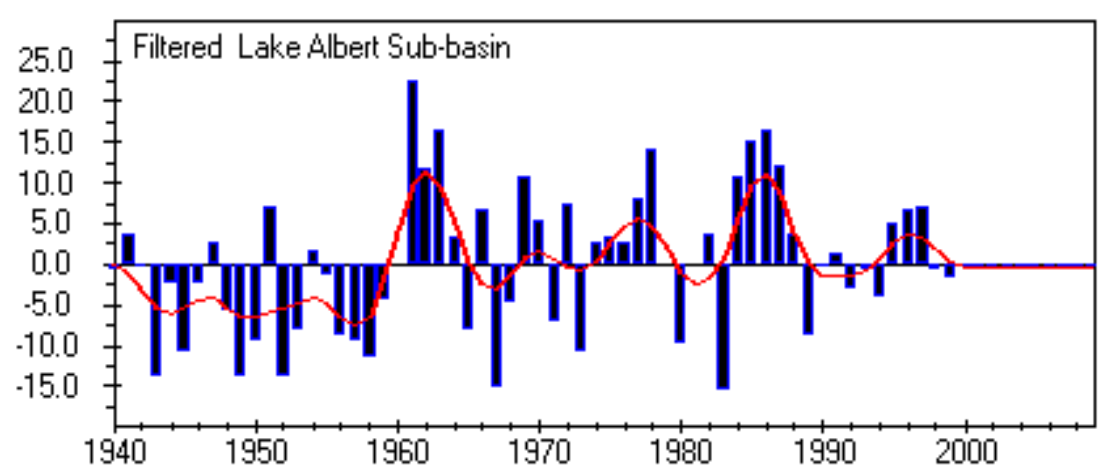

c)

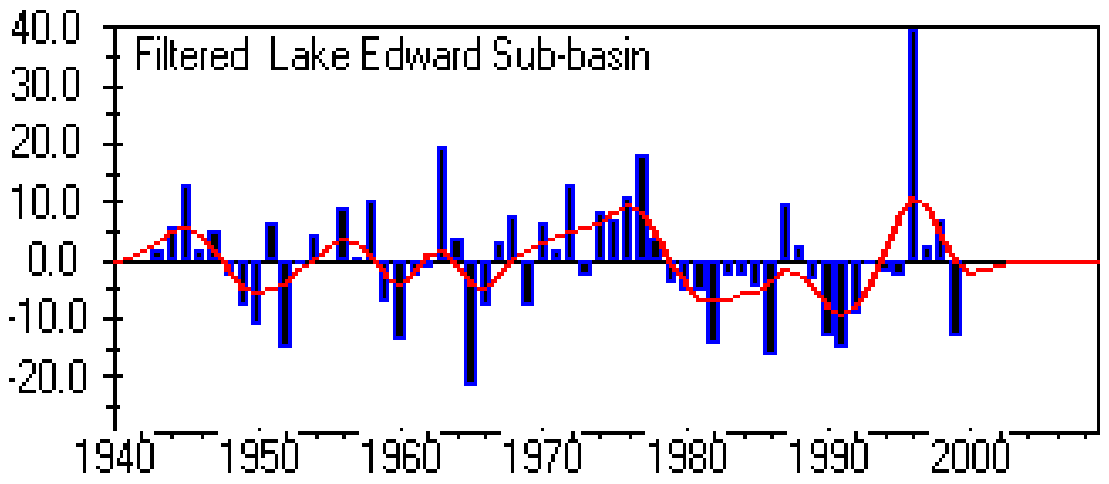

d)

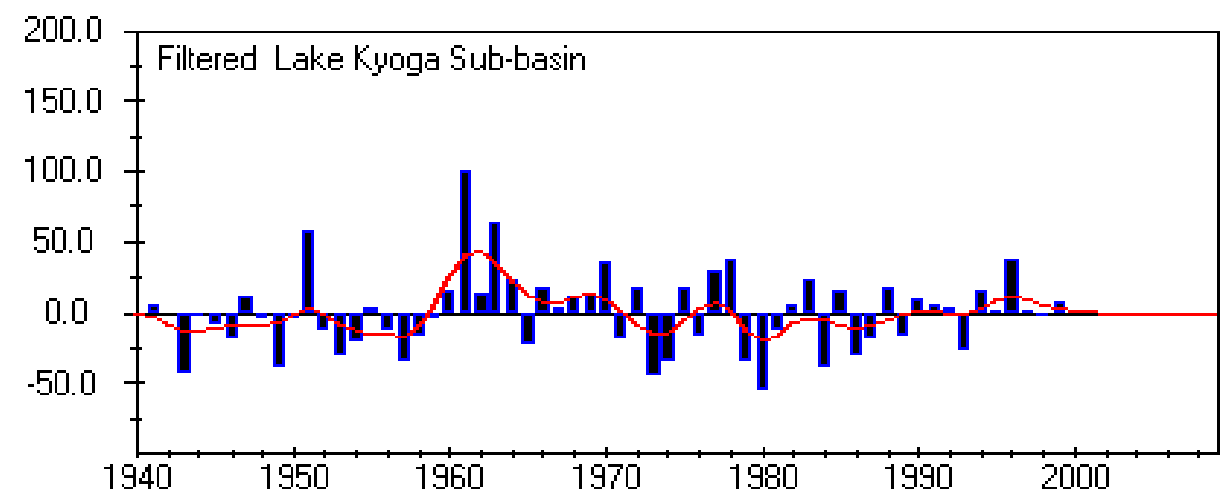

e)

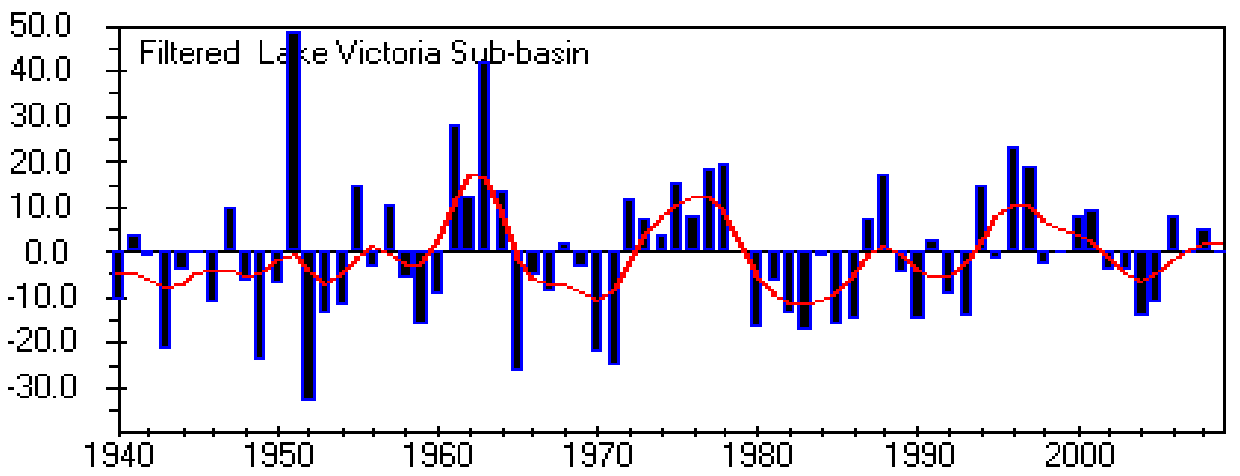




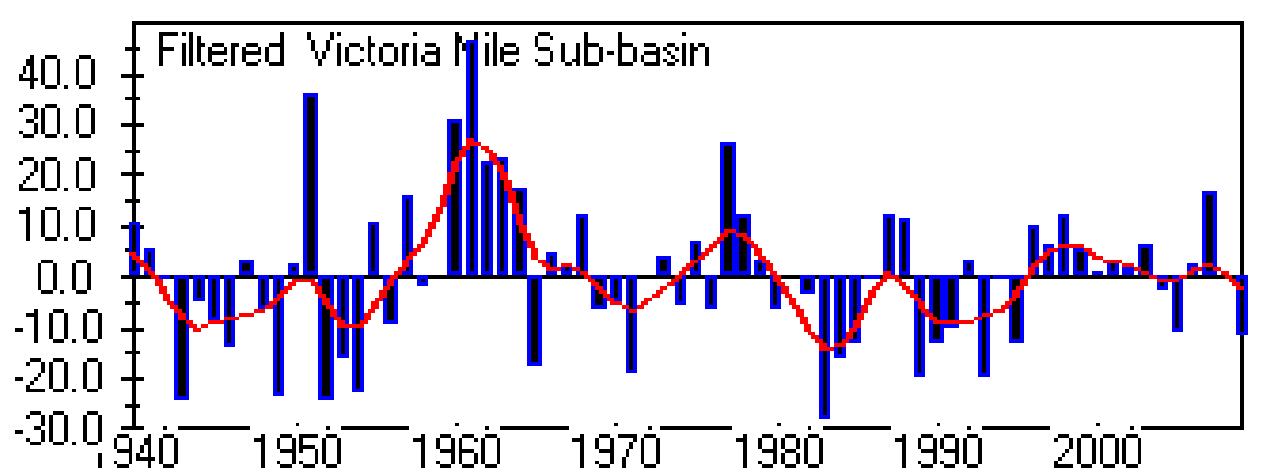

g)

Figure 8(a-g) Variations and trends in normalized annual rainfall anomalies series with ninepoint Gaussian filter, over the main drainage sub-basins of Uganda. 

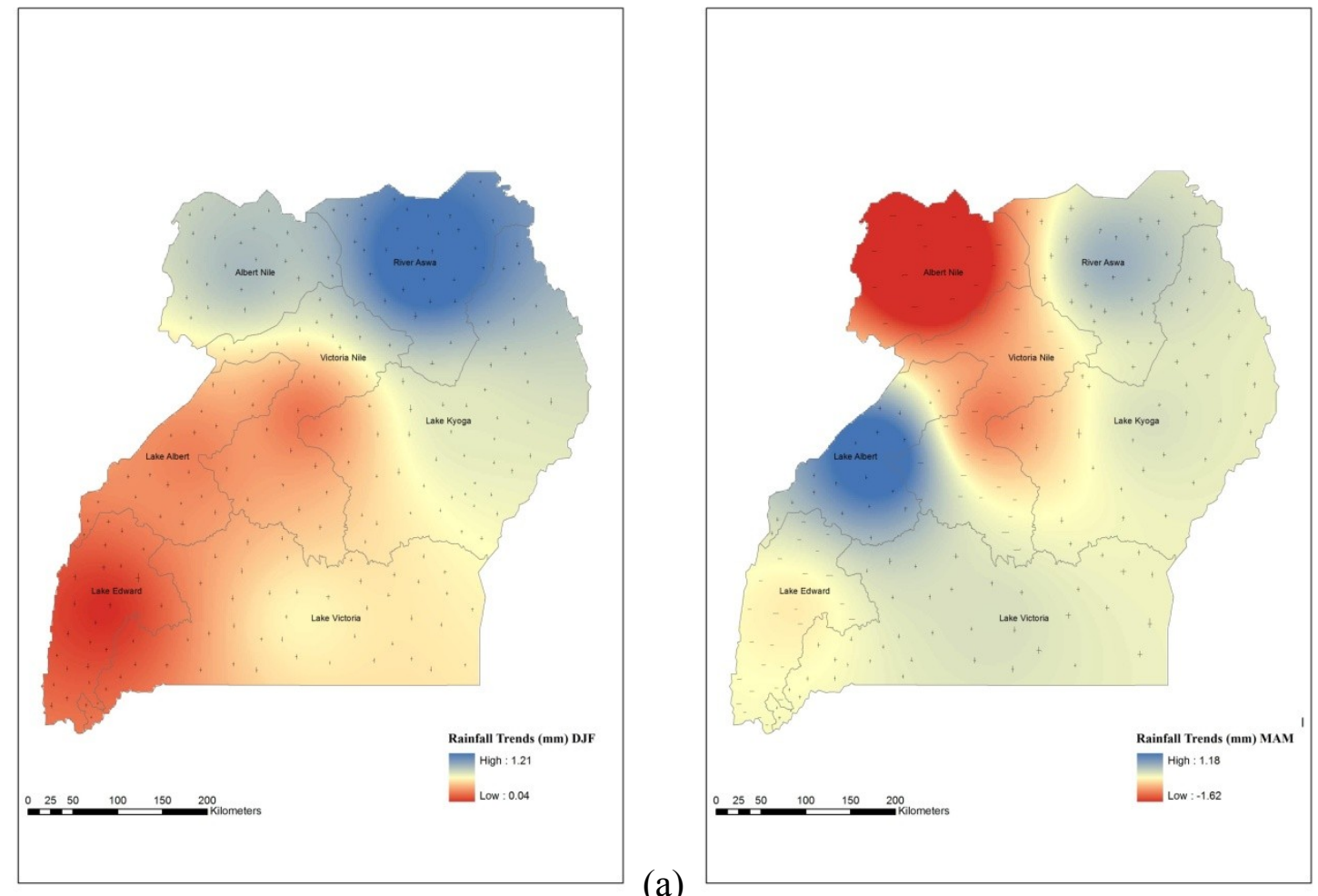

(b)
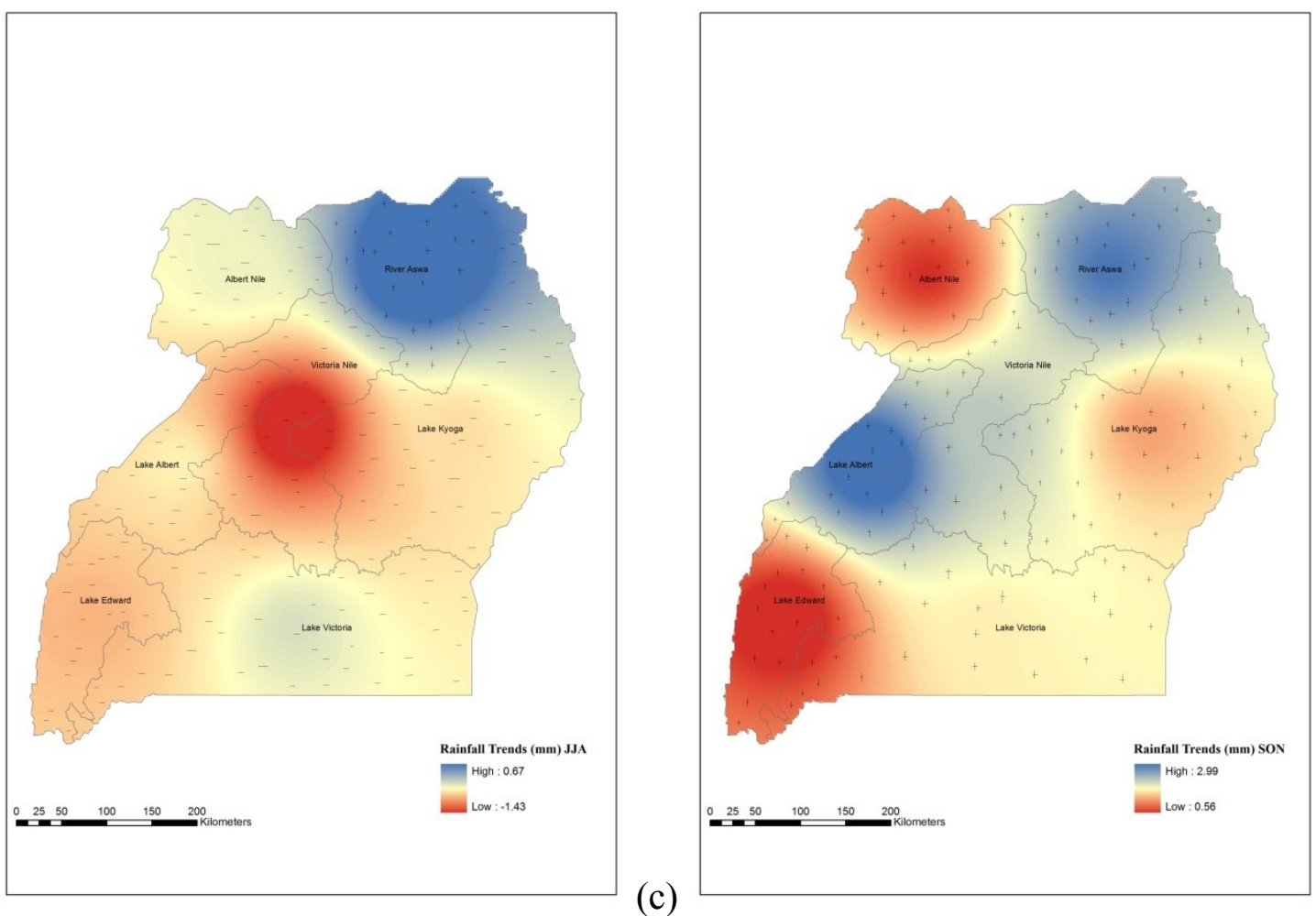

(d)

Figure 9(a-d) Shows the spatial distribution of negative (-) and positive $(+)$ trends for seasonal distribution of rainfall for the period 1940 - 2009 in Uganda's main drainage Sub-basins. Magnitude is in $\mathrm{mm} /$ season (not indicated on map). 
Table 1 Basic statistical characteristics of annual rainfall data for the 35 stations in the period 1940- 2009.

\begin{tabular}{|c|c|c|c|c|c|c|c|c|c|c|}
\hline $\begin{array}{l}\text { Drainage } \\
\text { Sub-basin }\end{array}$ & Station & $\begin{array}{l}\text { Mean } \\
\text { rainfall }\end{array}$ & $\begin{array}{l}\text { Highest } \\
\text { total } \\
\text { rainfall } \\
(\mathrm{mm})\end{array}$ & $\begin{array}{l}\text { Year of } \\
\text { occurence }\end{array}$ & $\begin{array}{l}\text { Lowest } \\
\text { total } \\
\text { rainfall } \\
(\mathrm{mm})\end{array}$ & $\begin{array}{l}\text { Year of } \\
\text { occurence }\end{array}$ & $\begin{array}{l}\text { Standard } \\
\text { deviation }\end{array}$ & $\begin{array}{l}\text { Serial } \\
\text { corr. } \\
\text { coeff. } \\
(95 \%)\end{array}$ & $\begin{array}{l}\text { Von- } \\
\text { neumann } \\
\text { Ratio } \\
(\mathbf{9 5 \% )}\end{array}$ & $\begin{array}{l}\mathrm{CV} \\
\%\end{array}$ \\
\hline \multirow{3}{*}{ Aswa } & Morulem & 1130 & 1672 & 1961 & 877 & 1968 & 15 & 0.2 & 1.4 & 15 \\
\hline & $\begin{array}{l}\text { Kitgum } \\
\text { Center }\end{array}$ & 1318 & 2042 & 1970 & 733 & 1918 & 21 & 0.17 & 1.6 & 18 \\
\hline & Patong & 1233 & 1920 & 1978 & 755 & 1959 & 21 & 0.2 & 1.4 & 21 \\
\hline \multirow{7}{*}{$\begin{array}{l}\text { Lake } \\
\text { Victoria }\end{array}$} & $\begin{array}{l}\text { Entebbe Int. } \\
\text { Airpot }\end{array}$ & 1617 & 2679 & 1999 & 1121 & 2004 & 24 & 0.17 & 1.6 & 18 \\
\hline & Jinja & 1312 & 1972 & 1963 & 871 & 1953 & 21 & 0.3 & 1.3 & 20 \\
\hline & Mbarara Met & 940 & 1522 & 1951 & 696 & 1952 & 13 & 0 & 2 & 17 \\
\hline & $\begin{array}{l}\text { Katigondo } \\
\text { WFM }\end{array}$ & 1222 & 2032 & 1984 & 753 & 1967 & 23 & 0.3 & 1.3 & 22 \\
\hline & Kamenyamigo & 1012 & 1506 & 1951 & 569 & 1992 & 17 & 0.2 & 1.5 & 21 \\
\hline & $\begin{array}{l}\text { Rwoho forest } \\
\text { sta }\end{array}$ & 985 & 1606 & 1951 & 540 & 1981 & 18 & 0.3 & 1.2 & 22 \\
\hline & Bakijulula & 1225 & 1987 & 1987 & 854 & 1989 & 18 & 0.3 & 1.3 & 17 \\
\hline \multirow{6}{*}{$\begin{array}{l}\text { Victoria } \\
\text { Nile }\end{array}$} & $\begin{array}{l}\text { Aduku } \\
\text { Variety }\end{array}$ & 1331 & 1712 & 1967 & 985 & 1952 & 13 & 0.2 & 1.5 & 12 \\
\hline & $\begin{array}{l}\text { Kakooge } \\
\text { Gombol }\end{array}$ & 1013 & 1695 & 1947 & 374 & 1974 & 27 & 0.3 & 1.2 & 29 \\
\hline & Kawanda Res & 1244 & 1737 & 1961 & 783 & 1983 & 20 & 0.2 & 1.5 & 20 \\
\hline & $\begin{array}{l}\text { Namulonge } \\
\text { Res }\end{array}$ & 1217 & 1747 & 1997 & 674 & 1989 & 18 & 0.3 & 1.2 & 17 \\
\hline & Gulu Met & 1559 & 2040 & 1970 & 1002 & 1943 & 20 & 0.06 & 1.8 & 15 \\
\hline & Ngetta Farm & 1447 & 1930 & 1963 & 1157 & 1973 & 15 & 0.09 & 1.8 & 13 \\
\hline \multirow{5}{*}{$\begin{array}{l}\text { Lake } \\
\text { Edward }\end{array}$} & Kasese Met & 897 & 1151 & 1993 & 676 & 1991 & 11 & -0.1 & 2.2 & 14 \\
\hline & Kabale Met & 1021 & 1477 & 1945 & 768 & 1948 & 12 & 0.17 & 1.6 & 14 \\
\hline & $\begin{array}{l}\text { Kachwekano } \\
\text { DFI }\end{array}$ & 1041 & 1480 & 1996 & 707 & 1960 & 13 & 0.24 & 1.5 & 15 \\
\hline & $\begin{array}{l}\text { Kirima Forest } \\
\text { sta }\end{array}$ & 1135 & 1526 & 1996 & 844 & 1969 & 13 & -0.09 & 2.1 & 13 \\
\hline & Rwashamaire & 1025 & 1401 & 1951 & 709 & 1946 & 15 & 0.3 & 1.2 & 18 \\
\hline \multirow{3}{*}{$\begin{array}{l}\text { Lake } \\
\text { Albert }\end{array}$} & Masindi Met & 1329 & 1733 & 1972 & 1014 & 1983 & 15 & 0.19 & 1.57 & 13 \\
\hline & Kijura factory & 1518 & 2024 & 1961 & 1147 & 1945 & 17 & 0.14 & 1.6 & 14 \\
\hline & Bulindi farm & 1342 & 2465 & 1984 & 1020 & 1957 & 24 & 0.19 & 1.6 & 21 \\
\hline
\end{tabular}




\begin{tabular}{|c|c|c|c|c|c|c|c|c|c|c|}
\hline \multirow{3}{*}{$\begin{array}{l}\text { Albert } \\
\text { Nile }\end{array}$} & Arua & 1443 & 1908 & 1955 & 1046 & 1931 & 15 & 0.2 & 1.4 & 13 \\
\hline & Nebbi UTC & 1064 & 1590 & 1961 & 585 & 1970 & 20 & 0.5 & 0.8 & 22 \\
\hline & Moyo Boma & 1309 & 1973 & 1951 & 875 & 1970 & 21 & 0.17 & 1.67 & 18 \\
\hline \multirow{9}{*}{$\begin{array}{l}\text { Lake } \\
\text { Kyoga }\end{array}$} & Tororo Met & 1462 & 1981 & 1961 & 879 & 1949 & 20 & 0.29 & 1.3 & 17 \\
\hline & Mutai forest & 1359 & 2238 & 1961 & 943 & 1973 & 18 & 0.04 & 1.9 & 15 \\
\hline & $\begin{array}{l}\text { Mukono } \\
\text { Agric }\end{array}$ & 1355 & 2244 & 1960 & 772 & 1972 & 26 & 0.5 & 0.8 & 23 \\
\hline & Kangole & 660 & 1089 & 1961 & 410 & 1962 & 14 & 0.02 & 2 & 25 \\
\hline & $\begin{array}{l}\text { Serere } \\
\text { Agric.Sta }\end{array}$ & 1376 & 2378 & 1996 & 939 & 1939 & 19 & 0 & 2 & 16 \\
\hline & Soroti Met sta & 1336 & 2032 & 1915 & 851 & 1957 & 21 & 0.1 & 1.7 & 19 \\
\hline & $\begin{array}{l}\text { Kibale } \\
\text { sta }\end{array}$ & 1361 & 2047 & 1961 & 626 & 1980 & 21 & 0.06 & 1.9 & 18 \\
\hline & Mbale & 1224 & 1789 & 1951 & 807 & 1927 & 19 & 0.16 & 1.7 & 19 \\
\hline & Kotido & 677 & 1145 & 1946 & 351 & 1965 & 16 & 0.15 & 1.7 & 28 \\
\hline
\end{tabular}

Table 2 Showing results from PCI calculations using temporal and seasonal concentration methods.

\begin{tabular}{|l|l|l|l|l|l|l|}
\hline Sub-basin & \multicolumn{2}{|c|}{$1940-2009$} & \multicolumn{2}{c|}{$1940-1969$} & \multicolumn{2}{c|}{$1970-1999$} \\
\hline & $\begin{array}{l}\text { Seasonal } \\
\text { concentration }\end{array}$ & $\begin{array}{l}\text { Temporal } \\
\text { concentration }\end{array}$ & $\begin{array}{l}\text { Seasonal } \\
\text { concentration }\end{array}$ & $\begin{array}{l}\text { Temporal } \\
\text { concentration }\end{array}$ & $\begin{array}{l}\text { Seasonal } \\
\text { concentration }\end{array}$ & $\begin{array}{l}\text { Temporal } \\
\text { concentration }\end{array}$ \\
\hline Albert Nile & 10.57 & 1.44 & 10.49 & 3.38 & 10.70 & 3.35 \\
\hline Lake Albert & 9.71 & 1.44 & 9.60 & 3.37 & 9.85 & 3.35 \\
\hline Aswa & 10.91 & 1.46 & 10.93 & 3.39 & 10.92 & 3.39 \\
\hline Lake Edward & 9.62 & 1.43 & 9.70 & 3.35 & 9.56 & 3.35 \\
\hline Lake Kyoga & 9.76 & 1.44 & 9.79 & 3.37 & 9.75 & 3.36 \\
\hline Lake Victoria & 9.67 & 1.44 & 9.69 & 3.37 & 9.73 & 3.36 \\
\hline Victoria Nile & 9.26 & 1.44 & 9.25 & 3.37 & 9.32 & 3.35 \\
\hline
\end{tabular}

Table 3 Temporal Rainfall characteristics in the main drainage Sub-basins of Uganda 


\begin{tabular}{|c|c|c|c|c|c|c|c|c|c|c|c|c|c|c|c|}
\hline \multirow{2}{*}{$\begin{array}{l}\text { Basins } \\
\text { Series } \\
\text { variables }\end{array}$} & \multirow{2}{*}{$\begin{array}{l}\text { Sub- } \\
\begin{array}{l}\text { Trend } \\
\text { tests }\end{array}\end{array}$} & \multicolumn{2}{|c|}{ Albert Nile } & \multicolumn{2}{|c|}{ River Aswa } & \multicolumn{2}{|c|}{ Lake Albert } & \multicolumn{2}{|c|}{ Lake Edward } & \multicolumn{2}{|c|}{ Lake Kyoga } & Lake & ictoria & Victo & a Nile \\
\hline & & $\mathbf{Z}$ & $\mathbf{Q}_{\mathrm{i}}$ & $\mathbf{Z}$ & $\mathbf{Q}_{\mathbf{i}}$ & $\mathbf{Z}$ & $\mathbf{Q}_{\mathbf{i}}$ & $\mathbf{Z}$ & $\mathbf{Q}_{\mathrm{i}}$ & $\mathbf{Z}$ & $\mathbf{Q}_{\mathrm{i}}$ & $\mathbf{Z}$ & $\mathbf{Q}_{\mathbf{i}}$ & $\mathbf{Z}$ & $\mathbf{Q}_{\mathbf{i}}$ \\
\hline & 1940-2009 & 1.42 & 0.02 & 2.05 & 0.01 & 0.65 & 0.01 & 0.08 & 0.00 & 1.14 & 0.04 & 0.46 & 0.01 & 1.01 & 0.02 \\
\hline & 1940-1969 & -0.43 & -0.02 & 0.41 & 0.01 & 0.43 & 0.03 & -0.48 & -0.03 & 0.11 & 0.03 & $\begin{array}{ll}-0.64 \\
\end{array}$ & -0.07 & -0.25 & -0.04 \\
\hline & 1970-1999 & 1.27 & 0.04 & 0.79 & 0.00 & -0.11 & -0.01 & 0.46 & 0.06 & 0.71 & 0.09 & 0.24 & -0.01 & -0.29 & -0.02 \\
\hline Year of & MX & 1955 & & 1977 & & 1963 & & 1998 & & 1970 & & 1963 & & 1963 & \\
\hline .....rainfall & Mn & 1946 & & 1946 & & 1946 & & 1983 & & 1968 & & 1989 & & 1949 & \\
\hline February & 1940-2009 & 0.57 & 0.00 & 1.16 & 0.00 & 0.46 & 0.00 & -0.37 & 0.00 & 0.85 & 0.01 & -0.83 & -0.01 & -1.22 & -0.03 \\
\hline & 1940-1969 & 0.23 & 0.01 & 1.11 & 0.06 & -0.43 & -0.03 & 1.27 & 0.07 & 1.03 & 0.26 & 0.96 & 0.08 & 1.25 & 0.17 \\
\hline & 1970-1999 & 0.05 & 0.00 & -0.92 & $\begin{array}{l}-0.02 \\
\end{array}$ & -0.54 & -0.04 & -0.43 & -0.03 & 0.14 & 0.02 & 0.31 & 0.01 & -1.14 & -0.11 \\
\hline Year of & Mx & 1969 & & 1968 & & 1979 & & 1979 & & 1978 & & 1964 & & 1964 & \\
\hline ......rainfall & Mn & 1945 & & 1946 & & 1962 & & 1997 & & 1962 & & 1989 & & 1946 & \\
\hline March & 1940-2009 & -0.15 & 0.00 & -0.17 & 0.00 & 0.40 & 0.00 & 1.36 & 0.01 & 0.84 & 0.02 & 1.61 & 0.04 & 0.27 & 0.01 \\
\hline & 1940-1969 & -0.04 & -0.00 & 0.18 & 0.00 & 0.89 & 0.04 & 0.12 & 0.00 & 1.64 & 0.29 & 1.21 & 0.10 & 2.03 & 0.19 \\
\hline & 1970-1999 & -0.04 & 0.00 & -0.40 & 0.00 & 0.61 & 0.04 & 0.79 & 0.07 & 0.50 & 0.10 & $\begin{array}{l}-0.03 \\
\end{array}$ & -0.00 & 0.43 & 0.04 \\
\hline Year of & Mx & 1957 & & 1970 & & 1985 & & 1974 & & 1970 & & 1978 & & 1960 & \\
\hline .....rainfall & Mn & 1953 & & 1945 & & 1946 & & 1982 & & 1973 & & 1949 & & 1949 & \\
\hline April & 1940-2009 & -0.49 & -0.00 & 1.54 & 0.01 & 0.51 & 0.00 & -1.15 & -0.01 & 0.02 & 0.00 & -0.72 & -0.01 & -1.88 & -0.04 \\
\hline & 1940-1969 & -1.57 & -0.06 & 0.00 & 0.00 & 0.75 & 0.03 & 0.41 & 0.02 & 0.11 & 0.01 & 0.00 & 0.01 & 0.71 & 0.06 \\
\hline & 1970-1999 & -1.48 & 0.05 & 0.43 & 0.00 & -0.89 & -0.05 & -1.25 & -0.11 & 1.39 & 0.17 & -0.34 & -0.02 & -0.25 & 0.03 \\
\hline Year of & Mx & 1947 & & 1946 & & 1963 & & 1982 & & 1947 & & 1963 & & 1966 & \\
\hline .....rainfall & Mn & 1969 & & 1969 & & 1945 & & 1999 & & 1969 & & 1952 & & 1945 & \\
\hline May & 1940-2009 & -1.83 & $\begin{array}{l}-0.02 \\
\end{array}$ & -0.41 & 0.00 & 0.72 & 0.00 & 0 & 0.00 & -0.19 & 0.00 & -0.90 & -0.02 & -0.43 & -0.01 \\
\hline & 1940-1969 & -1.32 & -0.07 & -1.03 & $\begin{array}{l}-0.03 \\
\end{array}$ & -1.46 & $\begin{array}{ll}-0.08 \\
\end{array}$ & -0.55 & -0.03 & 0.11 & 0.04 & -1.36 & -0.15 & -1.32 & -0.09 \\
\hline & 1970-1999 & 1.07 & -0.05 & -2.78 & $\begin{array}{l}-0.07 \\
\end{array}$ & $\begin{array}{c}-0.62 \\
\end{array}$ & -0.02 & 0.11 & 0.02 & -0.25 & 0.03 & $\begin{array}{l}-0.17 \\
\end{array}$ & $\begin{array}{c}-0.01 \\
\end{array}$ & 0.61 & 0.04 \\
\hline Year of & Mx & 1946 & & 1985 & & 1962 & & 1993 & & 1954 & & 1945 & & 1957 & \\
\hline .....rainfall & Mn & 1971 & & 1966 & & 1966 & & 1984 & & 1966 & & 1960 & & 1966 & \\
\hline June & 1940-2009 & -0.29 & 0.00 & 0.78 & 0.00 & 0.57 & 0.00 & -0.09 & 0.00 & 0.17 & 0.00 & 0.21 & 0.01 & -0.90 & -0.02 \\
\hline & 1940-1969 & -1.43 & -0.08 & -1.18 & $\begin{array}{l}-0.04 \\
\end{array}$ & $\begin{array}{l}-0.68 \\
\end{array}$ & -0.05 & -1.41 & -0.06 & $\begin{array}{l}-0.96 \\
\end{array}$ & -0.12 & 0.07 & 0.01 & 0.64 & 0.05 \\
\hline & 1970-1999 & 1.45 & 0.05 & -0.77 & -0.00 & -0.07 & -0.00 & -0.11 & -0.01 & -1.18 & -0.14 & 0.15 & 0.02 & -1.11 & -0.06 \\
\hline Year of & Mx & 1957 & & 1985 & & 1943 & & 1972 & & 1950 & & 1974 & & 1972 & \\
\hline .....rainfall & Mn & 1952 & & 1965 & & 1949 & & 1999 & & 1960 & & 1990 & & 1952 & \\
\hline July & 1940-2009 & 1.07 & 0.01 & 1.81 & 0.01 & 0.19 & 0.00 & 0.05 & 0.00 & -0.31 & 0.00 & 0.41 & 0.01 & -0.72 & -0.01 \\
\hline & 1940-1969 & -0.18 & $\begin{array}{ll}-0.01 \\
\end{array}$ & -1.57 & $\begin{array}{ll}-0.04 \\
\end{array}$ & -0.96 & -0.05 & -2.23 & -0.07 & -1.57 & -0.15 & $\begin{array}{l}-0.68 \\
\end{array}$ & -0.05 & -1.18 & -0.05 \\
\hline & $\begin{array}{l}1970-1999 \\
\end{array}$ & 0.30 & 0.01 & 0.48 & 0.00 & $\begin{array}{l}-0.68 \\
-0.0\end{array}$ & $\begin{array}{l}-0.03 \\
\quad-03\end{array}$ & -1.68 & -0.16 & $\begin{array}{l}-0.29 \\
\end{array}$ & 0.07 & 0.03 & 0.00 & -1.57 & -0.14 \\
\hline Year of & Mx & 1998 & & 1949 & & 1984 & & 1974 & & 1974 & & 1974 & & 1974 & \\
\hline .....rainfall & Mn & 1941 & & 1963 & & 1990 & & 1993 & & 1973 & & 1993 & & 1963 & \\
\hline August & 1940-2009 & -1.05 & $\begin{array}{ll}-0.01 \\
\end{array}$ & 0.57 & 0.00 & 0.73 & 0.00 & $\begin{array}{ll}-0.31 \\
\end{array}$ & 0.00 & $\begin{array}{ll}-0.84 \\
\end{array}$ & -0.01 & $\begin{array}{ll}-0.7 \\
\end{array}$ & -0.02 & -1.51 & -0.03 \\
\hline & 1940-1969 & -0.43 & 0.03 & -1.43 & $\begin{array}{l}-0.03 \\
\end{array}$ & -1.57 & $\begin{array}{l}-0.05 \\
\end{array}$ & -1.59 & -0.08 & -1.93 & -0.24 & -1.68 & -0.15 & -2.64 & -0.20 \\
\hline & $\begin{array}{l}1970-1999 \\
\end{array}$ & -1.59 & -0.05 & $\begin{array}{ll}-0.59 \\
\end{array}$ & $\begin{array}{l}-0.02 \\
\end{array}$ & $\begin{array}{c}-0.14 \\
\end{array}$ & $\begin{array}{ll}-0.01 \\
\end{array}$ & \begin{tabular}{ll|}
-1.61 \\
\end{tabular} & -0.15 & $\begin{array}{ll}-0.29 \\
\end{array}$ & -0.03 & 0.03 & 0.00 & $\begin{array}{l}-0.79 \\
\end{array}$ & -0.06 \\
\hline Year of & Mx & 1975 & & 1946 & & 1962 & & 1976 & & 1961 & & 1988 & & 1955 & \\
\hline .....rainfall & Mn & 1951 & & 1959 & & 1967 & & 1982 & & 1969 & & 1986 & & 1965 & \\
\hline September & 1940-2009 & -1.51 & -0.00 & 0.79 & 0.00 & 0.59 & 0.00 & -0.80 & \begin{tabular}{c|}
-0.01 \\
\end{tabular} & -0.29 & -0.00 & 0.39 & 0.01 & 0.62 & 0.01 \\
\hline & 1940-1969 & -0.61 & -0.02 & 0.11 & 0.00 & 0.04 & 0.00 & -1.95 & -0.09 & 0.46 & 0.09 & 0.25 & 0.01 & -0.07 & -0.00 \\
\hline & $1970-1999$ & -1.16 & -0.04 & -2.99 & -0.06 & -1.28 & $\begin{array}{l}-0.04 \\
\end{array}$ & -0.11 & -0.01 & -0.79 & 0.10 & 0.62 & 0.04 & -0.21 & -0.02 \\
\hline Year of & Mx & 1955 & & 1973 & & 1961 & & 1992 & & 1983 & & 1955 & & 2007 & \\
\hline .....rainfall & Mn & 1965 & & 1982 & & 1953 & & 1993 & & 1957 & & 1957 & & 1963 & \\
\hline October & 1940-2009 & 0.76 & 0.00 & 1.88 & 0.01 & 1.94 & 0.02 & 0.79 & 0.01 & 1.09 & 0.04 & 2.47 & 0.05 & 2.02 & 0.04 \\
\hline & 1940-1969 & 1.36 & 0.06 & 2.36 & 0.08 & 2.11 & 0.11 & -1.98 & -0.09 & 2.43 & 0.36 & 2.03 & 0.14 & 1.89 & 0.17 \\
\hline & 1970-1999 & 1.23 & 0.03 & $\begin{array}{l}-0.38 \\
\end{array}$ & -0.00 & 1.71 & 0.08 & 2.43 & 0.12 & 1.39 & 0.19 & 1.25 & 0.06 & 1.36 & 0.12 \\
\hline & Mx & 1965 & & 1983 & & 1965 & & 1983 & & 1972 & & 1961 & & 1961 & \\
\hline .....rainfall & Mn & 1943 & & 1943 & & 1947 & & 1963 & & 1979 & & 1943 & & 1947 & \\
\hline November & 1940-2009 & 1.34 & 0.01 & 2.08 & 0.01 & 2.36 & 0.03 & 0.65 & 0.00 & 2.05 & 0.06 & 1.00 & 0.03 & 1.19 & 0.03 \\
\hline & 1940-1969 & 1.21 & 0.06 & 0.39 & 0.02 & 1.71 & 0.10 & 0.16 & 0.00 & 0.68 & 0.14 & 1.86 & 0.25 & 1.57 & 0.18 \\
\hline & 1970-1999 & 1.20 & 0.06 & 0.39 & 0.02 & 1.71 & 0.10 & 0.16 & 0.00 & 1.89 & 0.21 & 1.86 & 0.25 & 1.57 & 0.18 \\
\hline Year of & Mx & 1961 & & 1961 & & 1961 & & 1987 & & 1961 & & 1961 & & 1961 & \\
\hline .....rainfall & Mn & 1950 & & 1956 & & 1943 & & 1981 & & 1950 & & 1947 & & 1947 & \\
\hline December & 1940-2009 & 2.11 & 0.02 & 0.37 & 0.00 & 0.17 & 0.00 & 0.13 & 0.00 & 0.72 & 0.02 & 0.84 & 0.02 & 0.30 & 0.01 \\
\hline & 1940-1969 & 0.93 & 0.06 & 0.02 & 0.01 & 1.34 & 0.09 & -0.34 & -0.02 & 0.57 & 0.14 & 0.79 & 0.08 & 0.82 & 0.07 \\
\hline & $\begin{array}{l}1970-1999 \\
\end{array}$ & 3.30 & 0.08 & 2.34 & 0.05 & 2.41 & 0.09 & 1.53 & 0.08 & 2.28 & 0.21 & 1.60 & 0.07 & 1.64 & 0.12 \\
\hline Year of & Mx & 1951 & & 1951 & & 1965 & & 1963 & & 1951 & & 1951 & & 1951 & \\
\hline .....rainfall & Mn & 1953 & & 1943 & & 1971 & & 1970 & & 1952 & & 1952 & & 1952 & \\
\hline Annual & 1940-2009 & $\begin{array}{ll}-0.98 \\
\end{array}$ & $\begin{array}{l}-0.03 \\
\end{array}$ & 0.11 & 0.31 & 1.56 & 0.05 & $\begin{array}{l}-0.69 \\
\end{array}$ & -0.02 & 0.44 & 0.03 & 1.02 & 0.09 & 0.15 & 0.01 \\
\hline & 1940-1969 & 0.21 & 0.03 & 0.11 & 0.03 & 0.93 & 0.21 & -0.48 & -0.09 & 1.68 & 0.73 & 0.79 & 0.24 & 1.36 & 0.53 \\
\hline & $\begin{array}{l}1970-1999 \\
\end{array}$ & 0.96 & 0.30 & -2.13 & $\begin{array}{ll}-0.24 \\
\end{array}$ & -0.36 & $\begin{array}{ll}-0.04 \\
\end{array}$ & -1.46 & -0.37 & 0.32 & 0.24 & 0.48 & 0.08 & 0.25 & 0.09 \\
\hline Year of & Mx & 1961 & & 1977 & & 1961 & & 1996 & & 1961 & & 1951 & & 1961 & \\
\hline .....rainfall & Mn & 1971 & & 1953 & & 1983 & & 1965 & & 1980 & & 1952 & & 1983 & \\
\hline DJF & 1940-2009 & 0.77 & 0.01 & 1.21 & 0.08 & 0.24 & 0.00 & 0.04 & 0.00 & 0.61 & 0.04 & 0.52 & 0.02 & 0.21 & 0.11 \\
\hline
\end{tabular}




\begin{tabular}{|c|c|c|c|c|c|c|c|c|c|c|c|c|c|c|c|}
\hline \multirow{4}{*}{$\begin{array}{l}\text { Year of } \\
\text {.....rainfall }\end{array}$} & $1940-1969$ & 0.39 & 0.05 & 1.21 & 0.08 & 0.86 & 0.13 & 0.62 & 0.09 & 1.16 & 0.61 & 0.68 & 0.12 & 0.89 & 0.21 \\
\hline & 1970-1999 & 2.11 & 0.18 & 0.52 & 0.02 & 0.68 & 0.06 & 1.00 & 0.12 & 1.75 & 0.45 & 1.08 & 0.09 & 0.68 & 0.12 \\
\hline & Mx & \multicolumn{2}{|l|}{1969} & \multicolumn{2}{|l|}{1969} & \multicolumn{2}{|l|}{1969} & \multicolumn{2}{|l|}{1998} & \multicolumn{2}{|l|}{1969} & \multicolumn{2}{|l|}{1998} & \multicolumn{2}{|l|}{1998} \\
\hline & Mn & \multicolumn{2}{|l|}{1946} & \multicolumn{2}{|l|}{1946} & \multicolumn{2}{|l|}{1946} & \multicolumn{2}{|l|}{1992} & \multicolumn{2}{|l|}{1949} & \multicolumn{2}{|l|}{1946} & \multicolumn{2}{|l|}{1967} \\
\hline \multirow[t]{3}{*}{ МАМ } & $1940-2009$ & -1.62 & -0.03 & 0.44 & 0.00 & 1.18 & -0.02 & -0.12 & 0.00 & 0.13 & 0.00 & 0.14 & 0.01 & -0.61 & -0.03 \\
\hline & 1940-1969 & -1.21 & -0.14 & -0.68 & -0.04 & -0.18 & -0.02 & 0.59 & 0.07 & 1.07 & 0.37 & -0.14 & -0.02 & 1.03 & 0.18 \\
\hline & 1970-1999 & 0.91 & 0.10 & -1.67 & -0.12 & -0.39 & -0.03 & -0.86 & -0.08 & 0.68 & 0.19 & -0.17 & -0.02 & 0.57 & 0.08 \\
\hline \multirow{2}{*}{$\begin{array}{l}\text { Year of } \\
\ldots \ldots \text { rainfall }\end{array}$} & $\mathbf{M x}$ & \multicolumn{2}{|l|}{1957} & \multicolumn{2}{|l|}{1982} & \multicolumn{2}{|l|}{1985} & \multicolumn{2}{|l|}{1967} & \multicolumn{2}{|l|}{1947} & \multicolumn{2}{|l|}{1963} & \multicolumn{2}{|l|}{1960} \\
\hline & Mn & \multicolumn{2}{|l|}{1971} & \multicolumn{2}{|l|}{1953} & \multicolumn{2}{|l|}{1955} & \multicolumn{2}{|l|}{1999} & \multicolumn{2}{|l|}{1973} & \multicolumn{2}{|l|}{1949} & \multicolumn{2}{|l|}{2007} \\
\hline JJA & 1940-2009 & -0.41 & 0.00 & 0.67 & 0.00 & -0.51 & -0.01 & -0.71 & -0.01 & -0.58 & -0.02 & -0.33 & -0.02 & -1.43 & -0.06 \\
\hline & 1940-1969 & -0.96 & -0.12 & -1.64 & 0.11 & -1.96 & -0.13 & -1.62 & -0.16 & -2.43 & -0.52 & -1.14 & -0.16 & -1.64 & -0.24 \\
\hline & 1970-1999 & -0.21 & -0.02 & -1.67 & -0.09 & -1.25 & -0.11 & -2.43 & -0.41 & -1.18 & -0.22 & -0.03 & -0.01 & -1.86 & -0.25 \\
\hline Year of & $\mathbf{M x}$ & 1961 & & 1946 & & 1984 & & 1996 & & 1961 & & 1974 & & 1961 & \\
\hline .....rainfall & Mn & 1951 & & 1959 & & 1990 & & 1965 & & 1960 & & 1960 & & 1990 & \\
\hline SON & $1940-2009$ & 0.78 & 0.01 & 2.64 & 0.03 & 2.99 & 0.06 & 0.56 & 0.00 & 1.30 & 0.06 & 1.65 & 0.07 & 2.07 & 0.08 \\
\hline & 1940-1969 & 1.07 & 0.08 & 1.78 & 0.12 & 2.50 & 0.19 & -1.41 & -0.11 & 1.93 & 0.56 & 1.75 & 0.31 & 1.89 & 0.33 \\
\hline & 1970-1999 & 1.30 & 0.07 & -2.35 & -0.13 & 1.00 & 0.07 & 021 & 0.04 & 1.28 & 0.36 & -0.20 & -0.02 & 1.03 & 0.14 \\
\hline Year of & Mx & 1961 & & 1983 & & 1961 & & 1996 & & 1961 & & 1961 & & 1961 & \\
\hline .....rainfall & Mn & 1943 & & 1943 & & 1943 & & 1979 & & 1957 & & 1957 & & 1943 & \\
\hline (sub-basin & SEN's T & -0.31 & & -3.91 & & -3.13 & & -0.91 & & -1.09 & & -1.36 & & 0.19 & \\
\hline
\end{tabular}

Table 4 Coefficients of correlations results between annual and seasonal rainfall departure series for main drainage sub-basins in Uganda.

\begin{tabular}{|l|l|l|l|l|l|l|l|}
\hline & Albert Nile & River Aswa & Lake Albert & Lake Edward & Lake Kyoga & Lake Victoria & Victoria Nile \\
\hline DJF & 0.6 & 0.4 & 0.4 & 0.6 & 0.7 & 0.7 & 0.5 \\
\hline MAM & 0.6 & 0.7 & 0.2 & 0.5 & 0.5 & 0.5 & 0.6 \\
\hline JJA & 0.5 & 0.6 & 0.7 & 0.3 & 0.3 & 0.2 & 0.3 \\
\hline SON & 0.6 & 0.6 & 0.4 & 0.7 & 0.4 & 0.5 & 0.5 \\
\hline
\end{tabular}

